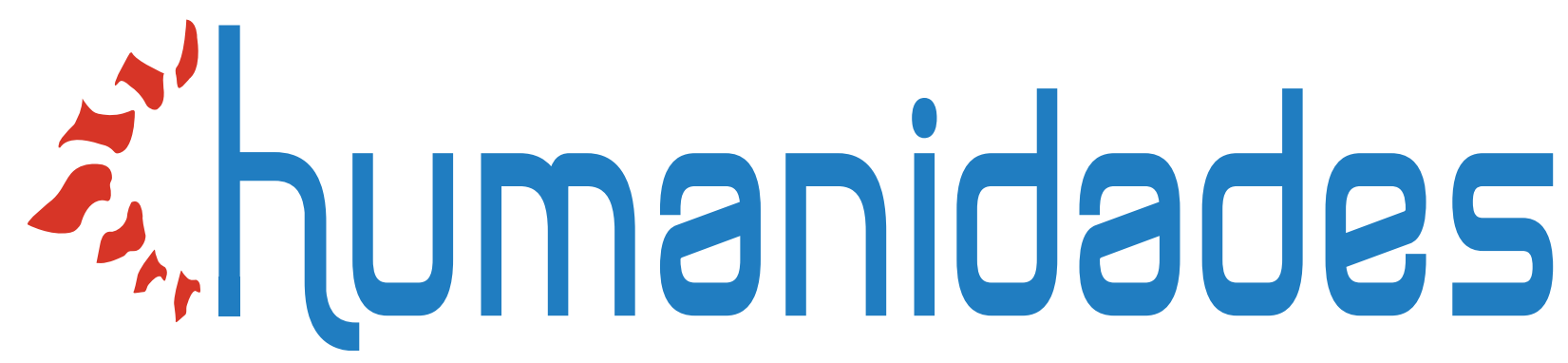

La construcción del pasado prehispánico como elemento identitario del territorio "mexicano", mediante una dinámica dialógica entre Nueva España y Occidente en los siglos XVII y XVIII

Eréndira Muñoz Aréyzaga

DOI: https://doi.org/I0.155 I7/h.v10i2.4II 95 https://revistas.ucr.ac.cr/index.php/humanidades/index

(c) $(7)(\mathrm{E}$

Universidad de Costa Rica 


\title{
"humanidades
}

Revista Humanidades

ISSN: 2215-3934

humanidades@ucr.ac.cr

Universidad de Costa Rica

Costa Rica

\section{La construcción del pasado prehispánico como elemento identitario del territorio "mexicano", mediante una dinámica dialógica entre Nueva España y Occidente en los siglos XVII y XVIII}

\author{
Muñoz Aréyzaga, Dra. Eréndira \\ La construcción del pasado prehispánico como elemento identitario del territorio "mexicano", mediante una \\ dinámica dialógica entre Nueva España y Occidente en los siglos XVII y XVIII \\ Revista Humanidades, vol. 10, núm. 2, 2020 \\ Universidad de Costa Rica, Costa Rica \\ Disponible en: http://www.redalyc.org/articulo.oa?id=498062469004 \\ DOI: https://doi.org/10.15517/h.v10i2.41195
}

Esta obra está bajo una Licencia Creative Commons Atribución-NoComercial-SinDerivar 3.0 Internacional. 
Desde los estudios étnicos, culturales, de género y ambientales

\title{
La construcción del pasado prehispánico como elemento identitario del territorio "mexicano", mediante una dinámica dialógica entre Nueva España y Occidente en los siglos XVII y XVIII
}

\author{
The Construction of the Pre Columbian Past as an Identity Element of the "Mexican" Territory, Through a \\ Dialogical Dynamic Between Nueva España and the West, in the 17th and 18th Centuries
}

Dra. Eréndira Muñoz Aréyzaga

Cátedras CONACYT - Universidad Autónoma del Estado

de México, Tenancingo, México

emunozar@conacyt.mx

http://orcid.org/0000-0002-2755-0120
DOI: https://doi.org/10.15517/h.v10i2.41195

Redalyc: http://www.redalyc.org/articulo.oa?

id $=498062469004$

Recepción: 21 Octubre 2019

Aprobación: 26 Febrero 2020

\section{Resumen:}

El patrimonio arqueológico mexicano es un atractivo turístico, su construcción como tal dependió de un proceso histórico en el que se entrelazaron la búsqueda de elementos identitarios para representar la idea de nación, en función de su auto y heterorreconocimiento, junto con los antecedentes de lo que hoy consideramos arqueología. Para conocer este proceso, se presenta una revisión de textos científicos novohispanos y occidentales sobre el pasado prehispánico, producidos entre los siglos XVII y XVIII, que representan su construcción como elemento identitario de una nación en ciernes. Este proceso estuvo mediado por la racionalidad que representó la Ilustración, la afirmación de la "leyenda negra" de España y por el movimiento político del nacionalismo criollo y español. Por lo tanto, la realización de dicho proceso histórico resultó de una dinámica dialógica, a veces contrapuesta, entre el Nuevo Mundo y Occidente, porque las condiciones políticas y culturales de ambos continentes facilitaron el hecho de que coincidieran en dar a la producción científica un uso identitario y nacionalista, el cual comenzó a representar a la nación mexicana tanto interna como externamente.

Palabras ClaVE: nacionalismo cultural, historia de las ciencias, arqueología, colonialismo.

\section{ABstraCT:}

The Mexican archaeological heritage is a tourist attraction, its construction depended on a historical process, intertwined with a search for identity elements to built a nation idea, based on its self and hetero recognition, along with the background of what we now consider archaeology. In order to know this process, a review of novohispano and western scientific texts about the preColumbian past, produced between the $17^{\text {th }}$ and $18^{\text {th }}$ centuries, that represent the process of its construction as an identity element, is presented. This process was mediated by the rationality that Enlightenment represented, the "leyenda negra" of Spain, and by Creole and Spanish nationalism. Thus, the realization of this historical process resulted from a dialogic dynamic between the New World and the West, because the politics and cultural conditions of both continents, facilitated the fact that they coincided in giving scientific production a nationalist use, which began to represent the Mexican nation internally and externally.

KEYWORDS: cultural nationalism, history of science, archaeology, colonialism.

\section{INTRODUCCIÓN}

El patrimonio arqueológico es clave para promocionar a México como un destino turístico y una oferta cultural consumida por quienes recorren el país. Sin embargo, su mercantilización se derivó de un proceso histórico porque antes de ser un atractivo turístico se construyó como un objeto de múltiples significados, al ser elemento narrativo de la otredad y del exotismo de los espacios donde la memoria, la identidad colectiva y la clave para entender la historia de las sociedades fueron conformando imaginarios que lo convirtieron de interés para el turismo. 
La condición principal que permitió la mercantilización del patrimonio fue el nacionalismo, ya que este permitió su construcción como elemento identitario del territorio mexicano y además cimentó una imagen con la cual presentarse a los otros, identidad hoy en día mercantilizada. El interés de este estudio es comprender el proceso del que se derivó la institucionalización del pasado prehispánico como elemento central de los discursos identitarios de la nación mexicana en ciernes entre los siglos XVII y XVIII. Mediante el análisis de la dinámica dialógica entre el Nuevo Mundo y Occidente, de la que dependió el auto y heterorreconocimiento del pasado prehispánico como un elemento identitario que facilitó el hecho de que se convirtiera en un referente del origen de la nación y de su pertenencia a ella, por consiguiente, comenzó eficientemente a representarla antes de que se constituyera como un estado independiente lo que posibilitó la idea de imaginarla soberana y difundir esa idea frente a los otros.

Este proceso se caracteriza por el reconocimiento del pasado prehispánico como un elemento vinculatorio entre el territorio y la comunidad que lo habita, una territoriedad de la que surge la construcción de una narrativa histórica del espacio novohispano. Después llegaría la apropiación de esa narrativa histórica y su transformación en un elemento identitario, impulsada por distintas condiciones políticas y culturales. Lo anterior requirió la producción de conocimiento sobre el pasado, inseparable de las condiciones políticas de su producción, el cual se refleja en un discurso para enaltecerlo y fortalecer su capacidad simbólica como elemento identitario y representar eficientemente a una nación en ciernes interna y externamente.

Desde el siglo XVI, en la Nueva España inició la construcción de un vínculo con el territorio que los españoles avecindados o nacidos allí consideraban propio, esto a la vez fue formando una idea histórica de su pasado derivada de la mirada occidental sobre el otro y plasmada en los primeros imaginarios del Nuevo Mundo difundidos en las crónicas de la conquista. Sin embargo, el nacionalismo encontró su cause a finales del siglo XVIII gracias a la lucha por redefinir el poder dominante frente al recrudecimiento del control de la corona española sobre sus colonias, bajo este panorama surgió la necesidad estratégica de construir un discurso nacionalista vinculado a la producción científica para fortalecer el colectivo de los criollos.

Este momento se contextualizó por la Ilustración, cuya racionalidad promovió en América y Occidente el uso científico de los vestigios del pasado como una fuente para construir la historia. En Occidente, la producción científica sobre el pasado novohispano, con tintes evolucionistas, se guió por la construcción de la "leyenda negra" de España que deslegitimaba la posesión de sus colonias. Este proceso facilitó que la producción científica novohispana se construyera mediante un diálogo, a veces contrapuesto, otras complementario, entre autores criollos y occidentales. Además, debido a las tensiones entre España y el resto de Europa surgió un nacionalismo español y la corona promovió estudios en sus colonias para escribir su historia, los cuales indirectamente afirmaron la identidad de la nación mexicana. De forma que, aunque en diferente momento, las condiciones políticas de ambos continentes facilitaron el hecho de darle a la producción científica un uso identitario, nacionalista.

\subsection{Conceptos clave y metodología}

La nación, según Benedict Anderson (2007), es una "comunidad política imaginada como inherentemente limitada y soberana” (p. 23), una colectividad cultural plenamente identificada con un territorio (Giménez, 2000). Por su parte, el nacionalismo refiere a la construcción de la idea de nación y a la búsqueda de elementos para representar un territorio que un colectivo imagina como propio, mediante los cuales se vincula a él y se cohesiona como grupo. Para Gilberto Giménez (2005) es un proceso identitario, del cual surge “una percepción colectiva de un 'nosotros' [...], por oposición a los 'otros', en función del (auto y hetero) reconocimiento de caracteres, marcas y rasgos compartidos" (p. 90). El nacionalismo precede a la formación del Estado. Inicia por el reconocimiento de las cualidades físicas y simbólicas del territorio, de su pasado y de su presente (Florescano, 1997; Giménez, 2005; Anderson, 2007), que resulta en la apropiación simbólico- 
expresiva del espacio, para crear, de acuerdo con Natividad Gutiérrez (2001), "una correspondencia de política, cultura y territorio como una sola entidad" (p. 26).

El nacionalismo novohispano se concibió de forma temprana por un proceso histórico cultural de hibridación entre la cultura india y la española, de la que resultó la cultura criolla. La palabra criollo, según Rosaura Hernández (1992), refiere a personas de origen español o europeo nacidos en América, por lo que desde el siglo XVI estas condiciones ya se cumplían, pero también, como señala Antonio Rubial (2002), corresponde a un movimiento cultural relacionado con un proceso identitario y podría aplicarse a quienes nacidos en Europa se asimilaron a la Nueva España y aportaron información para construir su identidad.

En la etapa que se analiza, el nacionalismo "vino emparejado de la producción de nuevos conocimientos, los cuales tomaron como base interacciones socioculturales para transformarlos en saberes" (Martínez, 2016, p. 13), los cuales representaron los antecedentes de la arqueología y al mismo tiempo legitimaron el discurso identitario de los criollos. Los criollos, básicamente, eran eclesiásticos y laicos. Los eclesiásticos, según Rubial (2002), construyeron elementos identitarios que tuvieron impacto social por su control sobre los medios de difusión, mientras que los laicos promovieron los valores que regularon "el ceremonial cortesano y los atributos jurídicos de un Estado [y difundieron] una cultura científica en la que se mezclaba el aristotelismo escolástico con las modernas corrientes cartesianas" (p. 73) para conformar elementos identitarios desde el punto de vista cultural y natural.

En la primera parte del trabajo se utilizan como fuentes de análisis textos de corte científico que produjeron los criollos sobre el pasado prehispánico, para estudiar su relación con este proceso identitario entrelazado con los antecedentes de la arqueología y la dinámica dialógica de la cual se asume que dependió. Primero se revisa la obra de Francisco Cervántes Salazar, de mediados del siglo XVI, para mostrar la paulatina apropiación de la historia antigua como una narrativa histórica del territorio novohispano y el proceso de territoriedad. Después las obras de Juan de Torquemada, Carlos de Sigüenza y Góngora, Agustín De Vetancurt, Lorenzo Boturini, Juan José de Eguiara y Eguren y los ilustrados Francisco Xavier Clavijero y José Antonio Alzate, puesto que representan el enaltecimiento del pasado prehispánico y la dinámica dialógica entre las visiones occidentales evolucionistas y las propias, cuyo resultado fue la reafirmación del elemento identitario.

En la segunda parte del trabajo, para mostrar el impacto del surgimiento del nacionalismo español en la construcción del pasado prehispánico como elemento identitario, se revisará el contexto en el que surgió y su asociación con los antecedentes de la arqueología española, las instrucciones que la corona española redactó para regular las comisiones científicas enviadas a la Nueva España, específicamente, la exploración de Palenque de Antonio del Río y la Real Expedición Anticuaria de Guillermo Dupaix; posteriormente, se concluye con la obra de Juan Bautista Muñoz que representa el último intento de la corona española por escribir una historia de las Indias para alimentar el nacionalismo español. Las fuentes mencionadas evidencian que en ambos continentes la racionalidad guío un proceso de redescubrimiento del pasado, el cual impactó en un proceso reflexivo de autoconocimiento que encontró un uso estratégico político.

Los textos revisados son considerados como un producto de la historia cultural, compuesto de múltiples miradas, representaciones e imágenes, "interaccionando con los procesos políticos, los económicos y los sociales, para dar una referencia general de los horizontes culturales que los permean y significan" (Pérez, 2006, p. 14), por lo que son sintomáticos de la sociedad y forman parte del pensamiento a la que ella está arraigada (Soriano, 2011) y se producen para cumplir con sus expectativas (Alburquerque, 2006). Así también, estos textos actúan como imaginarios del territorio y su pasado, el cual, históricamente, está relacionado con la construcción del exotismo de los espacios que posteriormente son mercantilizados. Daniel Hiernaux-Nicolas (2002) los define como:

Un conjunto de creencias, imágenes y valoraciones que se definen en torno a [...], un espacio, un periodo o una persona (o sociedad) en un momento dado. Es una construcción social-individual y colectiva en permanente remodelación-, [...] tejida en parte a partir de las interpretaciones fantasiosas que expresa el individuo sobre el tema imaginado (p. 8). 
Todos esos componentes textuales mencionados anteriormente reflejan el auto y heterorreconocimiento del hoy patrimonio arqueológico que ha fundamentado su construcción como un elemento definitorio del territorio que actualmente ocupa México.

\section{El PASADO PREHISPÁNICO Y LA FORMACIÓN DEL NACIONALISMO CRIOLLO}

\subsection{La construcción de la territorialidad}

En el siglo XVI, los imaginarios del territorio y de lo que hoy consideramos patrimonio arqueológico se derivaron de sus diferentes representaciones, dinamizadas por una relación desigual debido a la dominación española. Los primeros imaginarios del Nuevo Mundo se plasmaron en las crónicas de la conquista, su estructura narrativa estuvo permeada por los imaginarios que en Occidente se tenían sobre el otro, su cultura y su pasado antes del contacto español, por la literatura de viajes y textos de corte científico producidos en la Edad Media y el Renacimiento que se alimentaron de los autores clásicos, por la recuperación propia de este periodo.

Para los autores clásicos, como Heródoto, Pausanias, Plinio El Viejo, Estrabón o Tácito, los vestigios de las sociedades eran evidencia maravillosa de la creación humana y fueron recogidos en los primeros listados de las maravillas del mundo por sus cualidades físicas diferentes, estos se convirtieron en una forma de construir el exotismo de los espacios. La curiosidad o el interés científico transformaron a los vestigios en elementos narrativos del conocimiento y formaron parte de los primeros compendios del mundo conocido que presentaban interpretaciones sobre la construcción de los monumentos o el aporte de las sociedades antiguas, especialmente, la egipcia, la griega o la romana. El análisis auto reflexivo del devenir de las sociedades y la nostalgia griega por las ciudades caídas asoció a los monumentos del pasado a los discursos de memoria e identidad, cuando frente a la dominación romana los transformaron en marcas nemotécnicas para construir sus discursos identitarios.

En la Edad Media y el Renacimiento, los imaginarios de los objetos y monumentos del pasado de los otros se contextualizaron gracias al interés erudito de la escolástica por compendiar los saberes del mundo y la labor humanista renacentista de describir y clasificar las creaciones de la naturaleza, de Dios y las humanas, las cuales se convirtieron en una base para evaluar la calidad moral de las sociedades diferentes e interpretar su papel dentro de la historia providencialista o humanista, o en materiales susceptibles de coleccionarse en los gabinetes de curiosidades, estudios y galerías renacentistas.

La literatura de viajes representó el descubrimiento de los territorios desconocidos que ampliaron la geografía del mundo en la Edad Media y el Renacimiento y permearon la interpretación del indio americano, mediante una dinámica narrativa entre maravillas y monstruosidades, característica del primer periodo, que evidencia el proceso de distinguir, según Nieves Soriano (2011), "entre lo normal y lo patológico [...], lo racional y lo irracional, lo luminoso y la oscuridad [...]" (p. 259), el cual "depende del momento y de las condiciones culturales [...] y atañe a los diferentes ámbitos del ser humano: estética, patologías [...], costumbres" (p. 260).

Los episodios épicos de la literatura española, como el Amadis de Gaula, sumaron una cualidad descriptiva detallada de los escenarios donde ocurrían las batallas dignas de memorarse y permitieron la imaginación de los conquistadores como figuras heroicas que ejecutaban un mandato divino que cobraba sentido en la historia occidental de tipo providencialista. En este contexto, surgieron las crónicas de la conquista; en ellas, los templos, pirámides y objetos se construyeron como maravillosos por su diferencia, pero monstruosos por las prácticas para las que servían o que allí se llevaban a cabo, prácticas fuera de toda ética conocida y que sirvieron para justificar su destrucción, la dominación española y el llamado proceso civilizatorio del Nuevo Mundo. 
En Europa, para algunos humanistas como Pedro Mártir de Anglería, las técnicas para realizar los templos y las hoy antigüedades eran una muestra de la calidad moral y el desarrollo de los habitantes del Nuevo Mundo, reflexión que mostró en su obra De Orbe Novo. Mientras que, en la Nueva España, según Rubial (2002), algunos cronistas utilizaron sus escritos como "un recurso retórico para criticar la corrupción e infidelidad de los europeos [...] que permitía a Occidente descubrir sus propios valores perdidos" (pp. 85-86). Esta visión crítica les permitió a los franciscanos Andrés de Olmos, Toribio de Motolínia y Bernardino de Sahagún y al dominico Diego Durán escribir con cierta admiración sobre el pasado prehispánico, al considerarlo producto de una alta civilización y con ello sentaron las bases para enaltecerlo.

El proceso de nacionalismo inició con la búsqueda o creación de elementos definitorios del territorio habitado, condición denominada por Hernández (1992) como territoriedad, mediante la que los novohispanos reconocen desde el siglo XVI con la cual se identifican. Sus primeros rasgos identitarios se encuentran a partir el siglo XVI, alimentados por las crónicas de la conquista. Muestra de su inicio es la producción de imaginarios sobre la Ciudad de México, el centro político de la Nueva España. En este contexto, Cervántes, profesor de la Universidad de México, escribió México en 1554. Diálogos y de la misma forma que Pausanias, quien ocupó la nemotecnia para relacionar un hecho con un monumento con el fin de presentarle al lector a Grecia, el autor utiliza los edificios y lugares de la ciudad para dar a conocer el gobierno, la universidad y las costumbres de los indios a tres viajeros recién llegados, mediante diálogos imaginarios, de forma que su obra es cercana a la literatura de viajes.

El pasado prehispánico de la ciudad es referido en la introducción del segundo diálogo y mientras se desarrolla la plática con sus recién llegados. Cervántes (1875) reporta que la antigua ciudad se parecía a Venencia, "el terreno en que ahora está fundada, todo era antes agua, y por lo mismo los mexicanos fueron inexpugnables y superiores a todos los demás indios" (p.111). Resume quiénes eran, cómo vivían y algunas de sus costumbres las compara con la de los egipcios antiguos, como una estrategia para comunicarse con sus lectores y aportarles referentes conocidos o, tal vez, para colocar a los vestigios del México antiguo a la par de civilizaciones mejor valoradas en Occidente:

Los palacios de los reyes y principales eran sumamente magníficos [...]. Peleaban a pie, porque no conocieron los caballos [...]. En vez de espadas usaban macanas de madera, con navajas de pedernal [...] y se servían de rodelas para resguardarse [...]. Para hacerse fuertes contra los enemigos, aprovechábanse de cerros naturales hechos a mano, como de fortalezas o castillos, teniendo a gran honra morir en la guerra. Se comunicaban con los ausentes, no por medio de letras, sino de figuras de animales pintadas en ciertos papeles, a imitación de los egipcios (Cervántes, 1857, pp. 291-292).

Pero, la visión de Cervántes de los indios también es monstruosa. Desde lo alto de Chapultepec, afirma, "había otros cerros muchos más altos que este, hechos a mano [...]. Subíase hasta [...] una placeta; y [...] como reses en un rastro, sacrificaban y ofrecían a los ídolos víctimas humanas, sacándoles primero el corazón” (Cervántes, 1875, p. 279). Para Cervántes estas costumbres indias justificaban el proceso civilizatorio de España y además le permitieron interpretar su papel en la historia del Nuevo Mundo como uno de tipo providencialista, al considerar: “ $i C u a ́ n$ grande fortuna ha sido para los indios la venida de los españoles, pues han pasado de aquella desdicha a su actual felicidad, y de la antigua servidumbre a esta verdadera libertad!" (Cervántes, 1875, p. 279).

Asimismo, el texto del autor permite construir una imagen maravillosa del espacio citadino cuando escribe sobre su plaza principal, "no recuerdo ninguna, ni creo que en ambos mundos puede encontrarse igual [...] ¡qué adornada de altos y soberbios edificios por todos los cuatro vientos!” (Cervántes, 1875, p. 95). Además, el autor afirma que la ciudad y sus alrededores compendiaban dos mundos, una especie de microcosmos a la manera griega que lo mostraba todo, la geografía, la ciudad o acrópolis y los suburbios donde habitaban los indios, y también una especie de mestizaje entre la cultura española y la india que comenzaba a imaginar al territorio como un espacio sincrético: 
Me atrevo á afirmar que ambos mundos se hallan aquí reducidos y compendiados [...]. Los soberbios y elevados edificios de los españoles, que ocupan una gran parte del terreno [...], están por todas partes ceñidos y rodeados de las casas de los indios, humildes y colocadas sin orden alguno, que hacen veces de suburbios (Cervántes, 1875, pp. 279-280).

\subsection{La producción científica novohispana, el enaltecimiento del pasado y la construcción de una historia con raíces profundas}

La producción científica de los siglos XVII y XVIII, contextualizada en el segundo siglo por el desarrollo de la Ilustración, contribuyó a la recuperación y enaltecimiento del pasado prehispánico y a su apropiación como una narrativa histórica propia de la Nueva España que, previamente dividida en antes y después de la llegada de los españoles, se transformó en una sola con raíces profundas. Esto convirtió al pasado en objeto de estudio, cuyos acercamientos metodológicos conformaron los antecedentes de la arqueología en México, pero, sobre todo, en materia para construir "una entidad peculiar con un significado propio" (Benítez, 1995, p. 426) y la expresión de una identidad criolla, un "mexicanismo", un "amor a la patria".

En Occidente, el imaginario del territorio novohispano, antes basado en las crónicas de la conquista, se conformó por discursos científicos trapasados por el incipiente evolucionismo y por los relatos de viaje que, aunque pocos, presentaban visiones alejadas de la realidad. Los autores evolucionistas como el holandés Corneille De Pauw, el inglés William Robertson y los franceses George Luis Lecrerc, conde de Buffon y Francots Raynal, construyeron una narrativa de salvajismo y barbarie sustentada en la degeneración de la naturaleza por el trópico y, a la vez, ponían en duda el desarrollo histórico de las sociedades antiguas que denotaban las crónicas de la conquista. En este contexto, la comparación del pasado indígena con sociedades antiguas como la griega, la romana o la egipcia o, incluso, el hecho de considerar este pasado superior, se convirtió en una forma de dialogar con las visiones occidentales y en la clave de la imaginación de una nación con raíces propias.

A principios del siglo XVII, en 1615, se publicó La monarquía indiana de Torquemada, en la que se presenta la historia de la Nueva España desde antes del contacto español. El autor ocupa como fuentes los trabajos de sus compañeros de orden, como Sahagún y De Olmos; la Historia de la conquista de México del español Francisco López de Gómara, la obra de Cervántes y otros. Y a partir del aristotelismo escolástico dialoga con autores clásicos, y medievales, como San Agustín y otros de su tiempo, para enlazar "la historia del Viejo Mundo y el Nuevo en una sola y universal, haciendo de la segunda complemento de la ya conocida" (López, 1973, p. 19), ejercicio con el que comienza a enaltecer la historia antigua.

De Torquemada (s.f.) ordena una narrativa de la historia prehispánica de México y argumenta que primero estuvo poblado por gigantes, igual como se pensaba que había ocurrido en otras partes del mundo: "dicen que aquellos gigantes vinieron por mar y que hicieron guerra a los de la tierra y que edificaron edificios soberbios" (p. 53), periodo que se asoció con los teotihuacanos. Después estuvo habitado por toltecas que, afirma, "tenían conocimiento del Diluvio" (De Torquemada, s.f., p. 55), con lo que inserta la historia antigua en la historia providencialista occidental. Después se centra en el peregrinaje de los aztecas a Tenochtitlan, en sus gobernantes y compara a Tlotzin con Rómulo, fundador de Roma (De Torquemada, s.f., p. 99), también aborda la historia de los tlaxcaltecas, chichimecas y purépechas; posteriormente, trata la historia hispánica en donde describe la Ciudad de México y otras provincias.

El autor compara los templos prehispánicos con los de los antiguos griegos y egipcios y muestra su similitud mediante la descripción de algunas características arquitectónicas y espaciales de los templos de Atenas y Tebas. Según De Torquemada (s.f.), el número de templos era mayor en las sociedades antiguas porque "se sabe que aun los que más se preciaron de [...] adoradores de ídolos, ésos aun no se preciaron de edificarles muchas casas y templos" (p. 238), como los que calculaba se construyeron en el México antiguo. Al describir la Ciudad de México en la época colonial lo hace con cierta nostalgia, como la que tenían los antiguos griegos por las ciudades caídas, Torquemada considera recordar su pasado y afirma que no quedó nada de ella más que su asiento y aún así era diferente porque ya no existían las acequias y canales que la caracterizaban, y solo quedaba la "memoria de que en otro tiempo lo fue de otras gentes y naciones" (De Torquemada, s.f., p. 408). 
De Torquemada (s.f.), al igual que Cervántes, justifica el proceso civilizatorio español por la falsa religión e idolatría que profesaban los indios y del que resultó una ciudad ennoblecida, que contaba con los atributos de una república, recursos para abastecer a su población, las condiciones para el ejercicio de oficios diversos y para establecer y hacer cumplir un gobierno (p. 413). Su obra sirvió para enaltecer el pasado indígena mediante la estrategia comparativa con culturas antiguas como la romana, la griega y la egipcia, las cuales mediaron el diálogo con los autores occidentales. La historia antigua comenzó a ser idealizada, eran sociedades virtuosas por su cultura material y "su único defecto era estar en manos del demonio" (Hernández, 1992, p. 37). Los criollos comenzaron a ver la posibilidad de que el pasado prehispánico fuera un símbolo identitario y se empezó la construcción de dos personajes imaginarios, por un lado, el indio vivo, ese otro evangelizado, empobrecido, vencido, "vicioso" y, por otro, los indios que antes fueron.

De Sigüenza y Góngora, jesuita expulsado de esa orden, representa, para Laura Benítez (1995), "la cristalización de una cultura criolla, propia de América, derivada en parte de la occidental, pero a la que incorpora lo valioso indígena: el pasado" (p. 431). El jesuita fue uno de los literatos y científicos más representativos e influyentes del virreinato y se adelantó a su tiempo al considerar en sus estudios las ideas cartesianas, antes de que la Ilustración se difundiera plenamente, sus conocimientos llegaron a Europa al pertenecer a la corte de sabios de Luis XIV (Hernández, 1992 ; Bernal, 1992). Dentro de sus pertenencias tuvo antigüedades, documentos literarios e históricos con los cuales se propuso esclarecer la historia remota india convirtiéndolos en fuentes de conocimiento. De Sigüenza y Góngora (1683) afirma:

Me ha estimulado el sumo amor que a mi patria tengo, [establecer] [...] la serie y cosas de los chichimecas que hoy llamamos mexicanos, desde poco después del diluvio y hasta tiempos presentes, y esto no con menos pruebas que con demostraciones innegables por matemáticas (fol. Ixr, párr. 2).

Una de las labores más interesantes de De Sigüenza fue realizar la primera excavación arqueológica en Teotihuacán (Bernal, 1992). A diferencia de quienes afirman que Thomas Jefferson fue quien la hizo, Daniel Schávelzon (1983) muestra que la de De Sigüenza fue la primera en América y que la utilizó como un método experimental para comprobar la hipótesis de que los montículos de tierra de Teotihuacán eran pirámides construidas por antiguos indios. El autor muestra también rasgos de la escolástica, cuando consideraba "que los mexicanos eran descendientes de Neftuim, sobrino de Cam, y estos antepasados habían salido de Egipto, por eso eran constructores de pirámides" (Hernández, 1992, p. 37). Sus estudios sobre la genealogía de los gobernantes mexicas se convirtieron en metáforas para expresar el "mexicanismo". Carlos de Sigüenza fue encomendado en 1680 para realizar el programa iconográfico por el nombramiento del Virrey Paredes, uno de los grandes festejos del poder en la Nueva España. El autor escribió Teatro de virtudes politicas que constituyen a un príncipe advertidas en los monarcas antiguos del mexicano imperio y a partir de allí planteó que el arco triunfal elaborado para estas ocasiones se adornara con las efigies de los once emperadores mexicas, con Huitzilopochtli al centro, en lugar de las doce figuras clásicas occidentales que solían colocarse. Véase la Figura 1. 


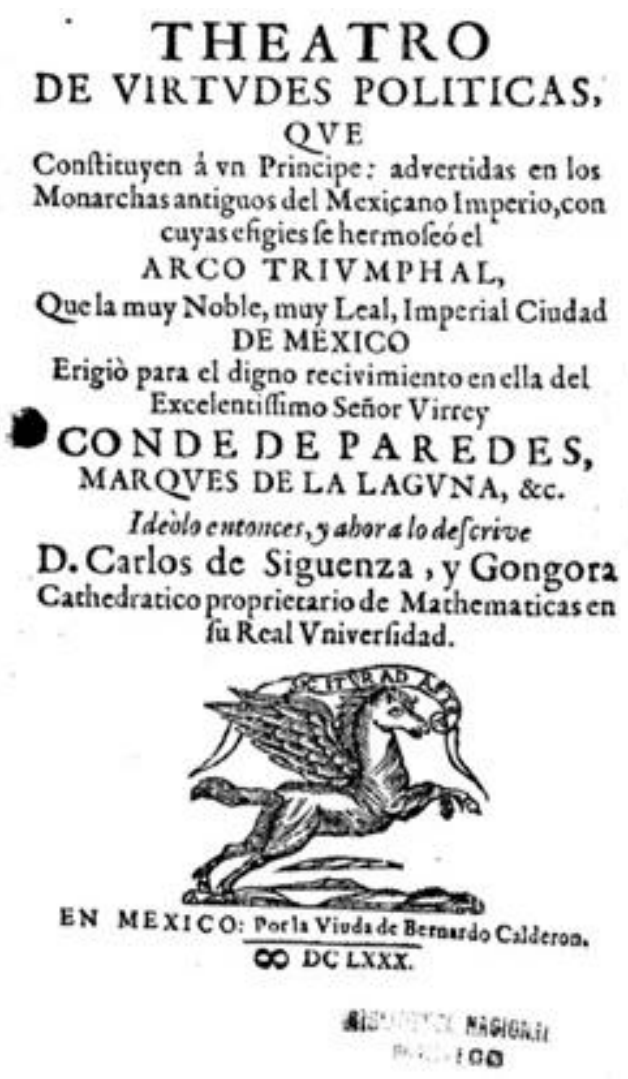

Figura 1.

Portada de Teatro de virtudes politicas que constituyen a un principe advertidas en los monarcas antiguos del mexicano imperio, Carlos de Sigüenza y Góngora, 1680.

El autor utiliza a los mexicas para explicar las virtudes políticas de todo gobernante, el primero era Huitzilopochtli. De Sigüenza debate la idolatría en la que Torquemada y Cervántes fundamentaban el proceso civilizatorio español y advierte que, si este monarca dios era conocido como "hechicero", esta palabra, "entre estos indios tenía la misma acepción que entre los de Paraguay, donde significaba: hombre admirable, milagroso, obrador de prodigios" (De Sigüenza, 1680, p. 38). Cada una de las descripciones de los emperadores es un canto de virtuosismo heroico y junto son sus obras Año mexicano, Imperio chichimeco, Tratado de grandezas de México, Historia antigua de los indios en estampas, Calendario de los meses y las fiestas de los mexicanos, Anotaciones criticas a las obras de Bernal Díaz del Castillo y Juan de Torquemada, aportó para que el pasado se convirtiera en una cultura propia y una estrategia política para imaginar una nación y una conciencia nacionalista.

Agustín de Vetancurt (1870) recurrió a mapas y documentos antiguos para escribir Teatro mexicano, publicado en 1698, con la intención de compendiar lo conocido de la historia de la Nueva España por quienes estuvieron allí y la escribieron de primera mano y agregar nueva información para el desengaño, porque al ser habitante de ella sentía el compromiso de hacerlo (pp. XV-XVIII). Véase la Figura 2. 


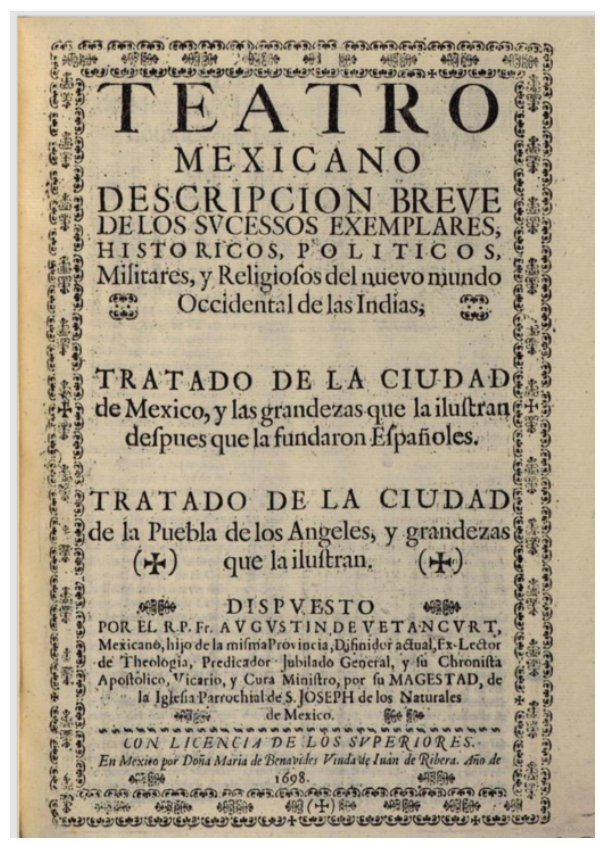

Figura 2.

Portada de Teatro mexicano. Descripción breve de los sucesos ejemplares históricos y politicos, militares y religiosos del Nuevo Mundo Occidental de las Indias, Agustín de Vetancurt, 1698.

Al estilo de la Geografía de Estrabón y el interés enciclopédico de Plinio El Viejo y su Historia Natural, al que se sumó el desarrollo que la botánica tuvo en ese siglo, dedica la primera parte de su obra a la geografía física, la flora y la fauna de la Nueva España. En ella, desde la escolástica, discute sobre el evolucionismo y la degeneración de la raza humana por el trópico, que llevaron a suponer que quienes vivían lejos de Europa serían hombres incultos e inferiores. Argumenta que Dios proveyó a esta tierra de tal temple que estuvo habitada por millones de personas desde la antigüedad y escribe su historia enalteciéndolos.

El autor recupera la estructura de Torquemada para narrar la historia de "los naturales de esta Nueva España”, desde sus orígenes hasta la llegada de los españoles y, como De Sigüenza, refiere a una sola historia desde el origen de la población indígena hasta la llegada de los españoles. Incluso los capítulos que abordan al pasado indígena los denomina como el pasado de la Nueva España, aunque no con el fervor de Carlos de Sigüenza que ya lo denominaba México. Además, critica el proceso de colonización y afirma, en oposición a Cervántes y Torquemada, que los indios antiguos, a pesar de ser idólatras, practicaban ceremonias y se regían a semejanza de las leyes divinas, que se perdieron por los españoles, sumiéndolos en los vicios (De Vetancurt, 1870), el Fray también argumenta que la riqueza de este territorio, atestiguada por los conquistadores y por los vestigios de los templos, "fue saqueada de sus originales dueños por los extranjeros y enriquecieron a todo el mundo" (p. 443). Al igual que Torquemada, Agustín de Vetancurt (1870) concluye su obra con una descripción de la antigua ciudad de México y retoma las descripciones de Cortés (pp.489-493), reafirmándola como una narrativa histórica propia del centro político de la Nueva España; y con la misma nostalgia que Torquemada, celebra que la ciudad se llame así en honor al que tal vez fuera su título en la antigüedad (pp. 495-496).

Lorenzo Boturini llegó a la Nueva España en 1736 y allí vivió nueve años. Se hizo de documentos y mapas que en principio le permitieran documentar la aparición de la Virgen de Guadalupe, pero sus intenciones fueron más allá. Escribió Idea de una nueva historia general de la América septentrional en la que incluyó el Catálogo del museo Indiano, para representar la historia de la Nueva España por regiones y culturas mediante su colección. Véase la Figura 3. 


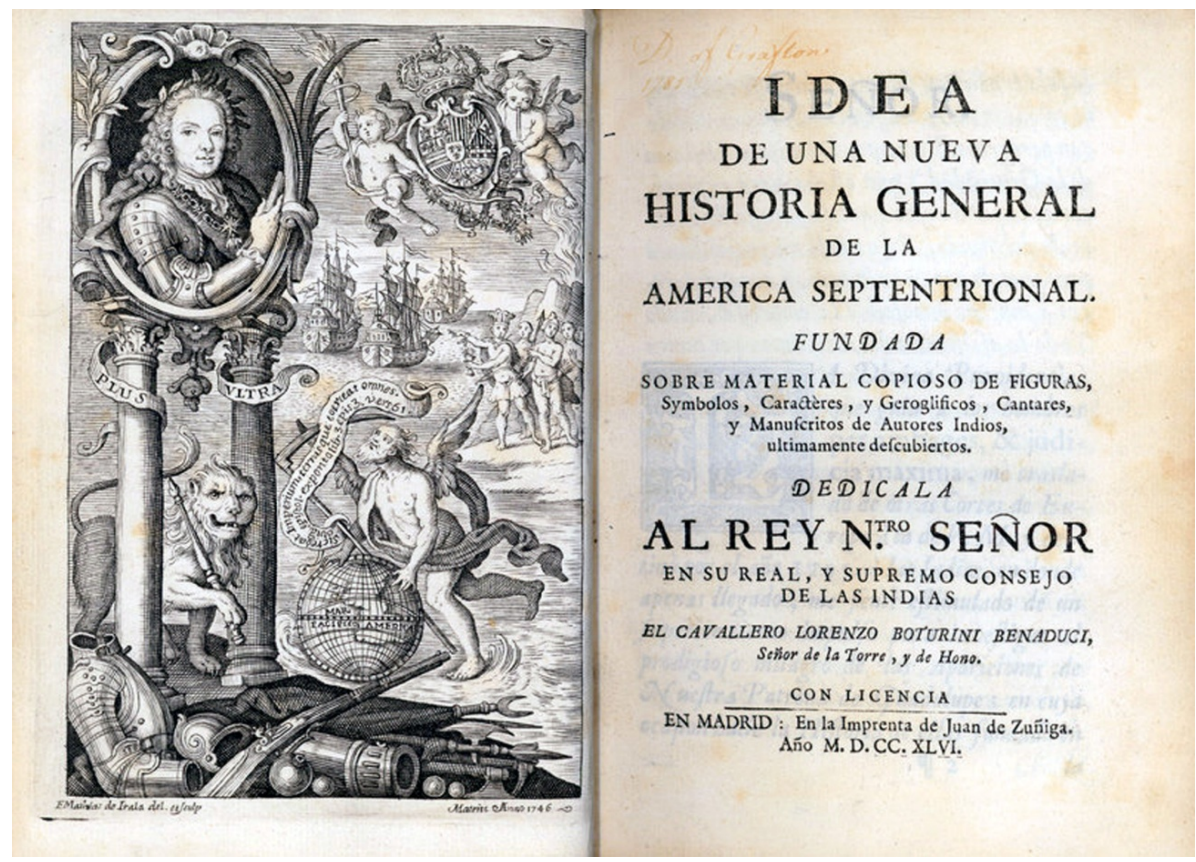

Figura 3.

Retrato de Boturini y portada de Idea de una nueva historia general de la América Septentrional, Lorenzo de Boturini, 1747.

Según Joseph Burrol, dictaminador de la obra, su objetivo era "indagar seriamente el origen de los indios [...], sus transmigraciones, gobierno, política, religión, idiomas, signos, jeroglíficos y pinturas con que explicaban entre los ausentes sus conceptos y dejaban a la posteridad memoria y noticia de sus hechos y acciones" (Burrol citado en Boturini, 1746, p. 1). Para Boturini (1746) el interés era denunciar de alguna forma los abusos de los españoles y establecer mediante la historia que los indios tenían derecho a "ser gobernados con justicia y que se promulguen leyes inteligibles verdaderamente humanas no fabricadas [...] con infinita desproporción" (p. 161). El autor intenta recomponer la imagen de los indios idólatras y bárbaros que permeaba en Occidente mediante dos estrategias; propuso, al estilo de Vetancurt, que el cristianismo era practicado antiguamente, cuando hizo una extraña relación entre Quetzalcóatl y Santo Tomás, y mediante la aplicación del modelo histórico de Vico, consideró que los indios representaban su última etapa, la de la "humanidad", la "racionalidad" y que, además, habían llegado allí antes que los españoles los dominaran.

Boturini fue desterrado de la Nueva España y su obra fue descalificada por la errónea aplicación del modelo de Vico. Sin embargo, su obra, difundida en Europa, afirmaba la importancia de los documentos y antigüedades y su necesaria conservación para interpretar el pasado. Al mismo tiempo que idealizó el pasado prehispánico, hizo un ejercicio de revalorar a los indios actuales al considerarlos como portadores de esa historia y denunciaba a España de haberlos subsumido por la colonización, aportando en Occidente a la afirmación de la "leyenda negra" de España.

De Eguiara, en su Biblioteca Mexicana publicada en 1755, conformó un catálogo de las obras de letrados indios, mestizos y criollos impresas en Nueva España desde su fundación. Su motivación fue una carta de Manuel Martí, deán de Alicante, dirigida a Antonio Carrillo para persuadirlo de no ir a la Nueva España porque aseguraba que era el "sitio de mayor barbarie del mundo entero, como país envuelto en las más espesas tinieblas de la ignorancia y como asiento y residencia del pueblo más salvaje que nunca existió o podrá existir en el futuro" (Hernández, 1992, p. 38). De Eguiara contestó póstumamente a Martí con el catálogo que representaba el conocimiento producido y afirma que "si alguna vez hubiera examinado los antiguos monumentos de nuestro país y hubiese hojeado las historias compuestas, ya por los españoles, ya por extraños, de ningún modo hubiese motejado de incultos a los indios mexicanos" (Hernández, 1992, p. 38). Al igual que De Sigüenza, Eguiara imagina al territorio de la Nueva España como independiente, como un lugar que 
no se asemeja a la visión occidental; la manera de dialogar en sus textos es a través de la producción científica que existía y el enaltecimiento del pasado indígena.

Al final del siglo XVIII, el jesuita Clavijero, después de la expulsión de los de su orden, escribió desde el exilio en Italia Historia antigua de México, por la misma motivación que De Sigüenza, por amor a la patria, a la que consideraba suya aún desterrado. Tenía una visión crítica sobre los abusos de la colonización española y una trayectoria criolla de estudios sobre historia antigua y su exilio le permitió conocer de primera mano la imagen de esa historia en Occidente a partir de las obras de Robertson, Buffon o De Pauw, aparte de leerlos también pudo debatir con ellos y con otros más reaccionarios como Jefferson (Sebastiani, 2011). Clavijero ocupa el recurso de enaltecer a los mexicanos antiguos por medio de dos acontecimientos, uno es la cruzada criolla nacionalista y el otro, según José Lameiras (1979), constituye la denuncia "del etnocentrismo europeo y los intereses coloniales" (p. 114), en este sentido, puede decirse que Clavijero también afirma en Occidente la "leyenda negra" de España. Esta denuncia tiene dos vertientes, la primera es una crítica que evidencia los abusos de la colonización y la consecuente degradación de los indios, al respecto Clavijero (1945c) dice que como un ejemplo "funesto de justicia divina y de la inestabilidad de los reinos de la tierra, que a pesar de las cristianas y prudentes leyes de los Monarcas Católicos [los indios quedaron] abandonados a la miseria, a la opresión y el desprecio" (pp. 313-314). La segunda es la crítica desde el punto de vista científico que, desde la mirada occidental etnocentrista, justificaba el proceso de colonización y derivaba en interpretaciones erróneas, en una historia, según Clavijero (1945a), llena de vicios “errores, despropósitos y mentiras” (p. 50).

Mediante esta crítica científica, que no se separa de su cruzada nacionalista, enaltece a los antiguos mexicanos cargándolos de cualidades morales positivas, considerándolos incluso superiores que algunas antiguas culturas occidentales. En oposición a los autores evolucionistas, Clavijero (1945a) afirma que el alma y razón de los indios eran igual que cualquier otra y los enaltece:

Jamás han hecho menos honor a su razón los europeos, que cuando dudaron de la racionalidad de los americanos. La policía que vieron los españoles en México, muy superior a la que hallaron los fenicios y los cartagineses en nuestra España, y los romanos en las Galias y en Gran Bretaña (p. 167).

Sobre la religión, que se convirtió en la primera justificación moral de la conquista y en clave para etiquetar a los antiguos mexicanos como bárbaros y crueles, Clavijero (1945d) afirma que "era menos supersticiosa, menos irracional que las de las más cultas naciones de la antigua Europa, y que de su crueldad ha habido ejemplos, y tal vez más atroces en casi todos los pueblos del mundo" (p. 392). Véase la Figura 4 y la Figura 5. 


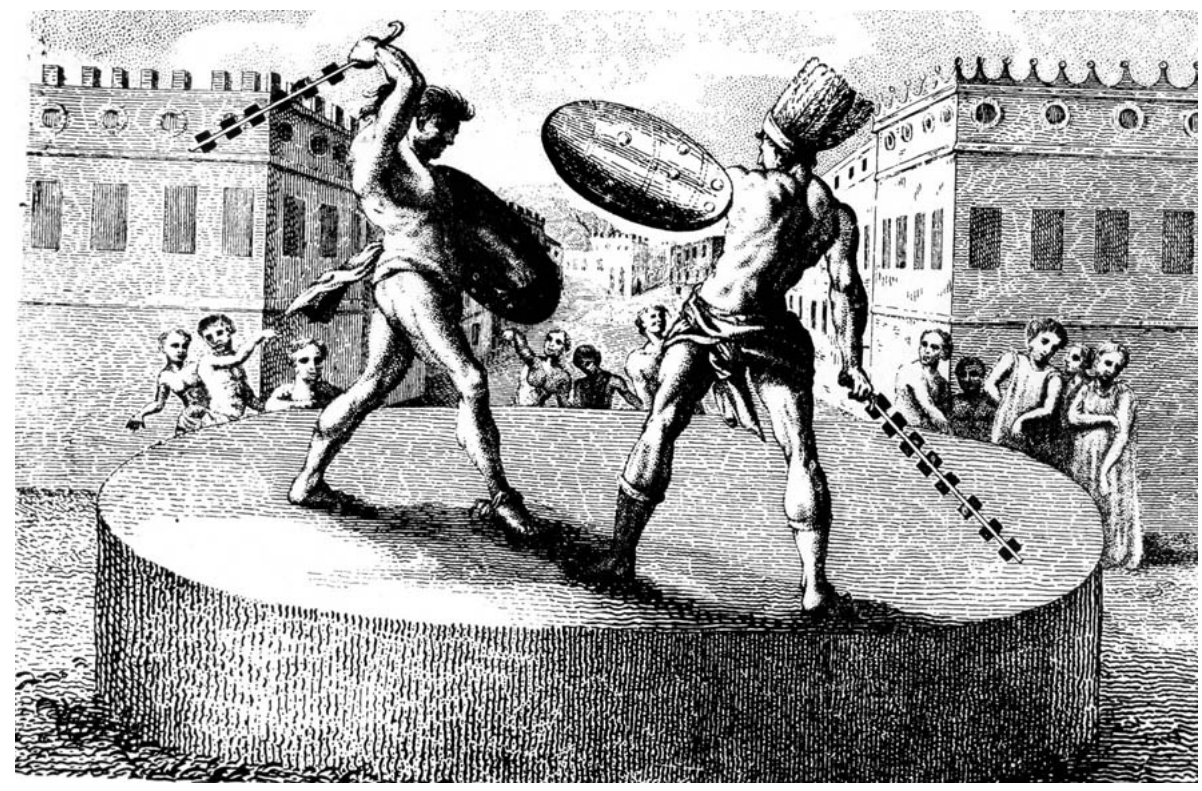

Figura 4.

Sacrificio gladiatorio. Historia Antigua de México. Tomo II, Francisco Xavier Clavijero, 1945, p. 124.

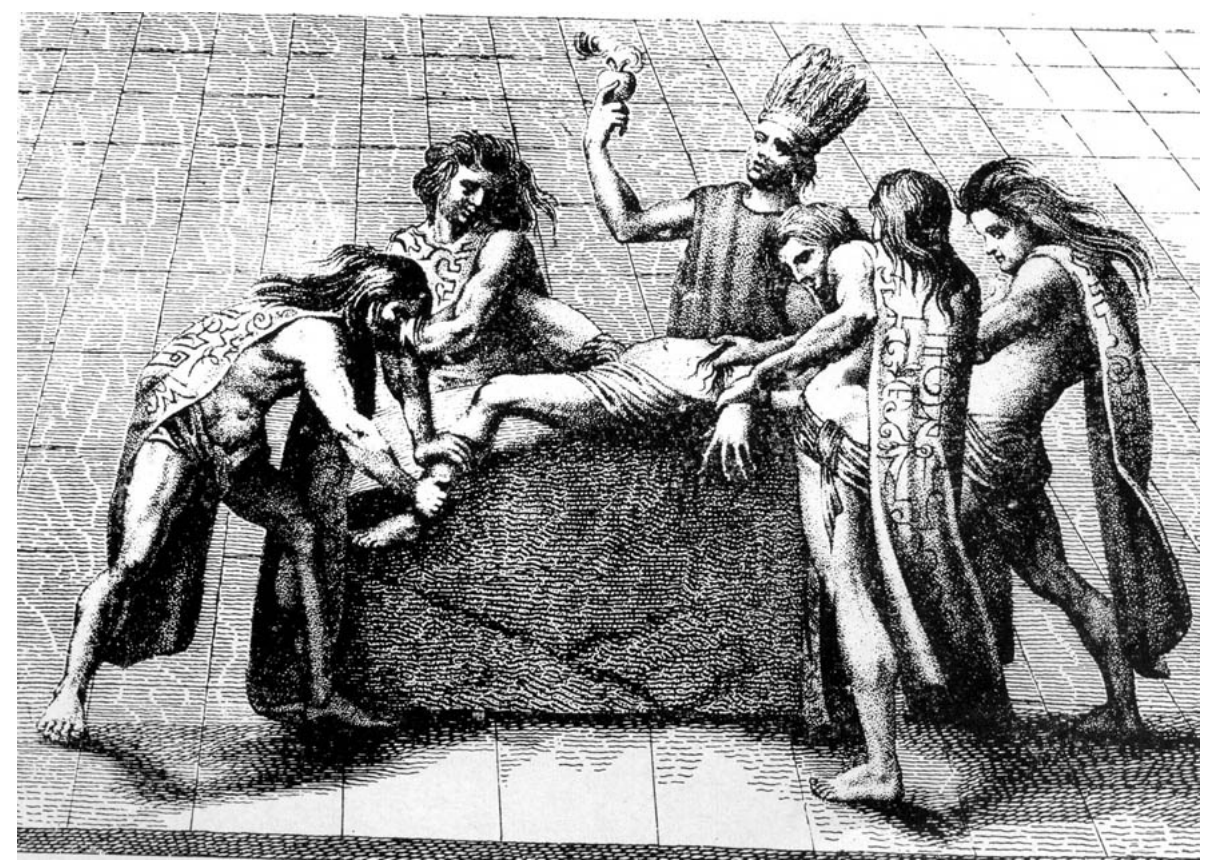

Figura 5.

Sacrificio ordinario. Historia Antigua de México. Tomo II, Francisco Xavier Clavijero,1945, p. 120.

Como puede observarse en las Figuras 6 y 7, Clavijero también enaltece los edificios antiguos y denuncia la destrucción de la que fueron objeto, sobre esto afirma:

De todos estos palacios, jardines y bosques, no ha quedado más que el bosque de Chapultepec, que conservaron para su diversión los virreyes. De lo demás casi nada dejaron en pie los conquistadores, arruinaron los más suntuosos edificios de la antigüedad mexicana [...] abandonaron el cultivo de los jardines y sitios deliciosos de los reyes de México [...] y dejaron la tierra en tal estado, que hoy no sería creíble la magnificencia de aquellos reyes, si no constase por el testimonio de los mismos que lo arruinaron" (Clavijero, 1945b, p. 19). 


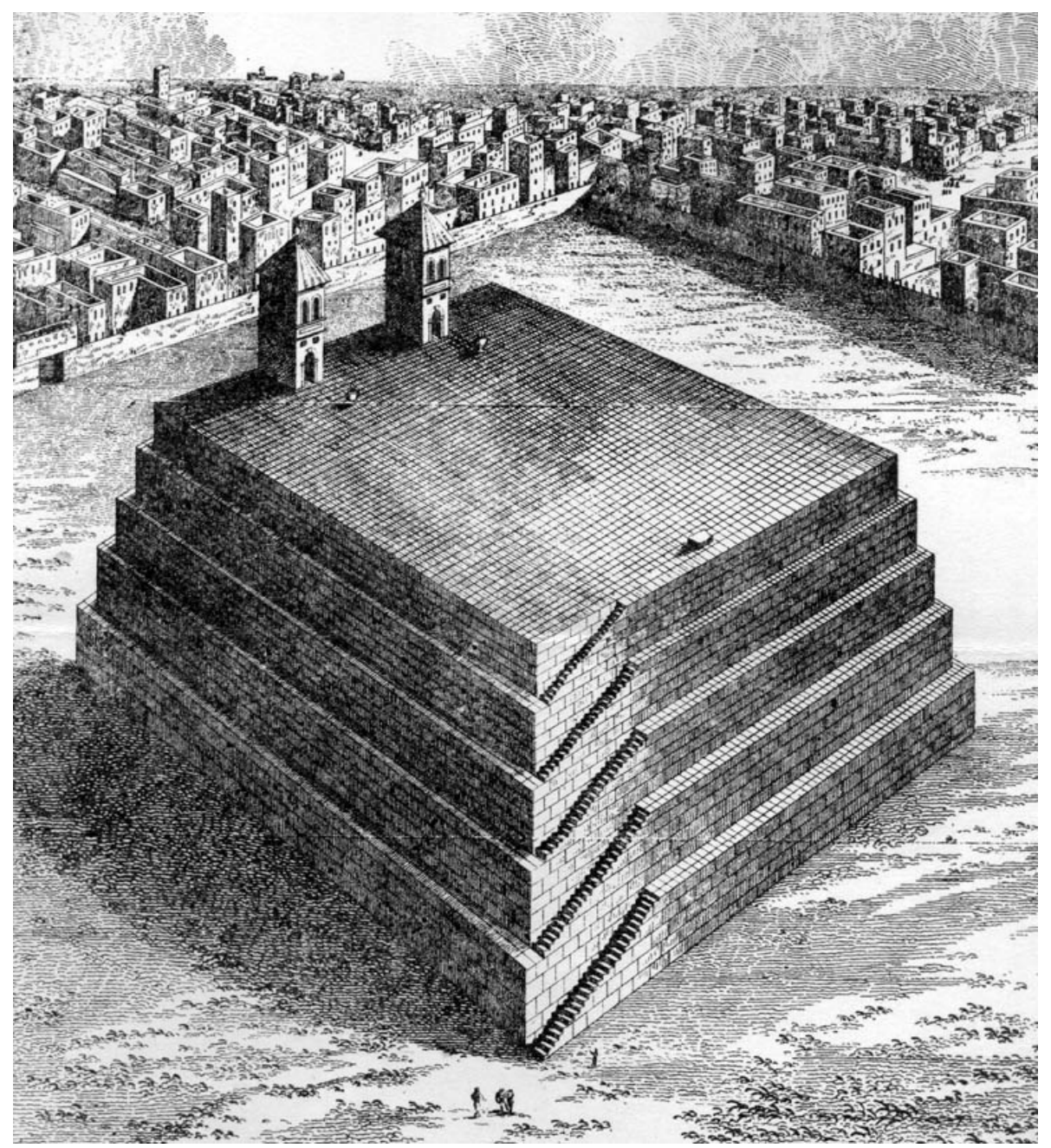

Figura 6.

El Templo Mayor de México. Historia Antigua de México. Tomo II, Francisco Xavier Clavijero, 1945, p. 97.

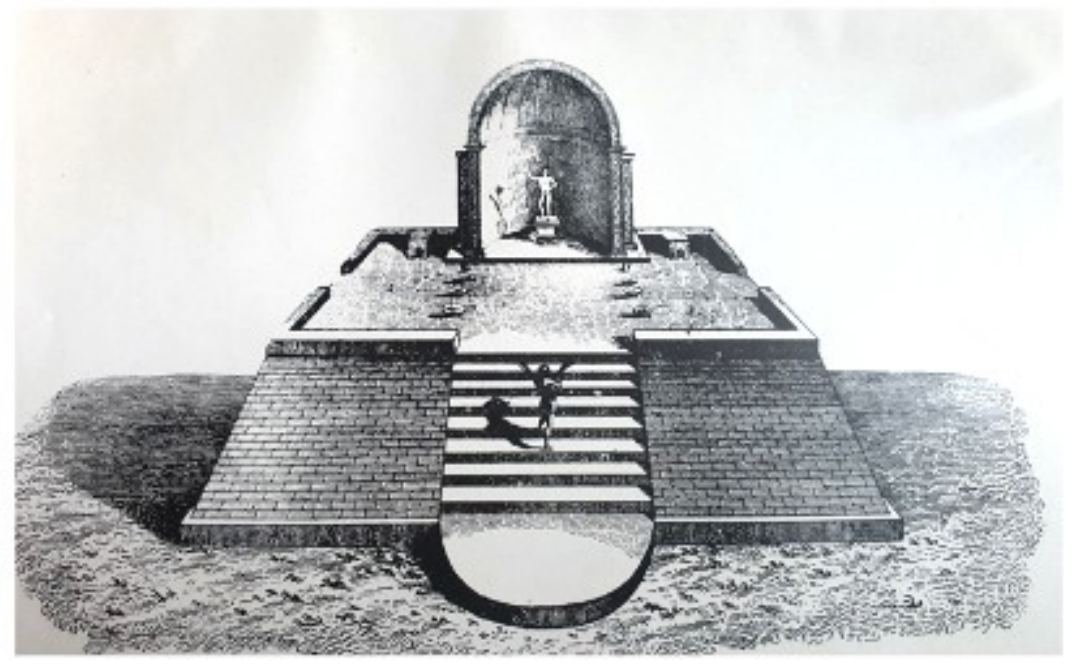

Figura 7.

Otro ejemplo de templo. Historia Antigua de México. Tomo II, Francisco Xavier Clavijero, 1945, p. 105. 
En su afán por denunciar la destrucción de documentos y antigüedades, propuso la recuperación de la memoria, mediante su estudio metódico y la conservación de los restos de "nuestra patria" para la creación de un museo que reuniera:

las estatuas antiguas que se conservan o que se vayan descubriendo en las excavaciones, las armas, las obras de mosaico y otros objetos semejantes, las pinturas mexicanas esparcidas por varias partes y sobre todo los manuscritos así de los misioneros y otros antiguos españoles como los de los mismos indios que se hallan en las librerías de algunos monasterios, de donde se podrán sacar copias antes de que los consuma la polilla o se pierdan (Clavijero, 1945a, p. 22).

Clavijero reforzó el imaginario de grandeza del pasado de México y alimentó la construcción del nacionalismo criollo, pero su discurso se dirigió al exterior. Su obra en Inglaterra y Estados Unidos se convirtió en la base de diversos estudios y alimentó las aspiraciones nacionalistas de los criollos y, de acuerdo con Silvia Sebastiani (2011), también la de los estadounidenses. Su discusión directa con De Pauw y especialmente con Robertson convirtió a su obra en fuente para el artículo "América" de la Enciclopedia Británica de 1778 y desde allí influenció para que "la representación del Nuevo Mundo y de sus habitantes divulgada en todo el mundo británico, antes negativa, pasara a ser fuertemente positiva” (Sebastiani, 2011, p. 227).

Alzate fue un importante científico novohispano, letrado en filosofía, geometría, teología, ciencias naturales, física e historia y al igual que De Sigüenza y Clavijero dialogó con los occidentales De Pauw y Robertson ya que perteneció a distintas asociaciones académicas en España y Francia. En 1788 fundó la Gazeta de literatura de México, su importancia era tal que era leída en la Corte de Madrid. En ella se publicaron documentos de su autoría y de otros y fortaleció el conocimiento científico mediante su divulgación y la idea de nación desde un punto de vista cultural y natural (De Pedro, 2009).

En 1792 publicó Descripción de las antigüedades de Xochicalco, reportó sus características arquitectónicas y urbanísticas, calculó su tamaño, infirió sus funciones militares e hizo dibujos y planos del sitio (López, 2010, p. 213). En el prólogo explica que su motivación por indagar el origen, costumbres, artes y ciencias de los indios, es el desprecio, la ignorancia y las mentiras que los extranjeros han escrito sobre ellos. “ $i$ Dichoso yo si esta [...] memoria que publico, llega a disipar las falsas impresiones que han causado los literatos de las siniestras noticias que acostumbran dar generalmente los estrangeros (sic) de los antiguos indios mexicanos en sus obras!" (Alzate, 1792, párr. 3). Alzate (1792), al igual que Clavijero, denomina a la Nueva España como la nación mexicana, que "debe reputarse por antigua; porque una vez avasallada por la nación española [...] perdió aquellos caracteres que la distinguen de otras naciones" (p. 2).

El autor recupera esos caracteres con su indagación en Xochicalco y evidencia que la cultura material es una herramienta para recuperar el pasado. Alzate (1792) afirma que un "edificio manifiesta el carácter y cultura de las gentes: porque es cierto que la civilidad o barbarie se manifiesta por el progreso que las naciones hacen en las ciencias y artes [...]" (p. 1). "Xochicalco hace patente el poder y cultivo de los mexicanos" (p. 6). Sus aportes a la ciencia y a la arqueología no se desvincularon de su fervor nacionalista y traspasaron las fronteras novohispanas, impactando en Occidente al cambiar la imagen del pasado. Véase la Figura 8. 


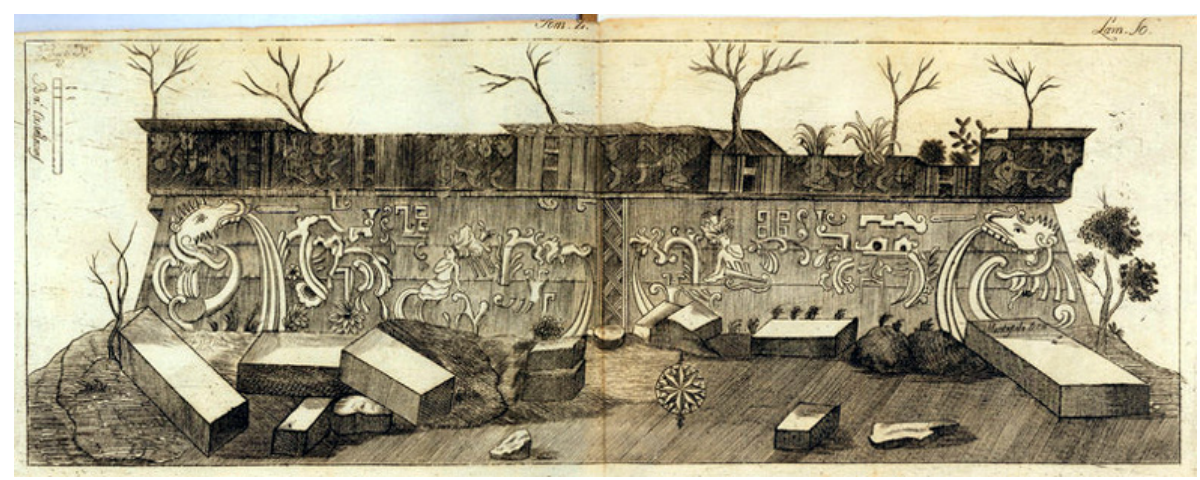

Figura 8.

Lámina 3. Suplemento de la Gazeta de Literatura. Descripcion de las antiguedades de Xochicalco, Alzate, 1791, p. 31.

Alzate entregó los dibujos de Xochicalco a Alejandro Malaspina que, de 1789 a 1794, con José de Bustamante, realizó un viaje diplomático por las colonias españolas y otros lugares del mundo, reportado en Viaje politico-cientifico alrededor del mundo por las corbetas Descubierta y Atrevida. Malaspina consideró mantener contacto con Alzate por la importancia que tenían sus indagaciones y el científico le dedicó su reporte de Xochicalco, porque conocía la importancia diplomática de la expedición y porque también con él viajaba una comisión científica que se referirá en la segunda parte del trabajo. El interés de Malaspina en dicho reporte no era precisamente el pasado indígena, sino mostrar que la navegación española era tan eficiente como la de los ingleses y dio importancia a la búsqueda estratégica de recursos y a los cálculos para determinar su ubicación, para crear rutas de acceso más rápidas. Por ello no refiere a la investigación arqueológica de Alzate, sino a sus ejercicios para determinar la ubicación de los edificios de la Ciudad de México (Malaspina y De Bustamante, 1885, p. 400).

Sin embargo, al tratar de las costumbres de la ciudad, Malaspina y De Bustamante (1885) reportan que Chapultepec era un importante lugar de recreo, en donde se construyó "un palacio [...] sobre las ruinas de otros que tuvo allí el emperador Moctezuma” (p. 403). También reporta sobre los vestigios de ciudades antiguas, en un área cercana a Sonora, que describe como laberintos hechos de paredes gruesas, construidas con una especie de argamasa formada por tierra, piedras menudas y arenas gruesas y considera son prueba de las migraciones humanas hacia el Sur (Malaspina y De Bustamante, 1885).

Los dibujos de Alzate también fueron recibidos por Pedro José Márquez, jesuita expulsado al igual que Clavijero, quien escribió Due Antichi Monumenti di Architectura Messicana: illustrati (Dos monumentos antiguos de la arquitectura mexicana ilustrados), en el que se presentan los dibujos de Xochicalco y otros de El Tajín que habían sido publicados de forma anónima en la Gazeta de Literatura. Véase la Figura 9. 


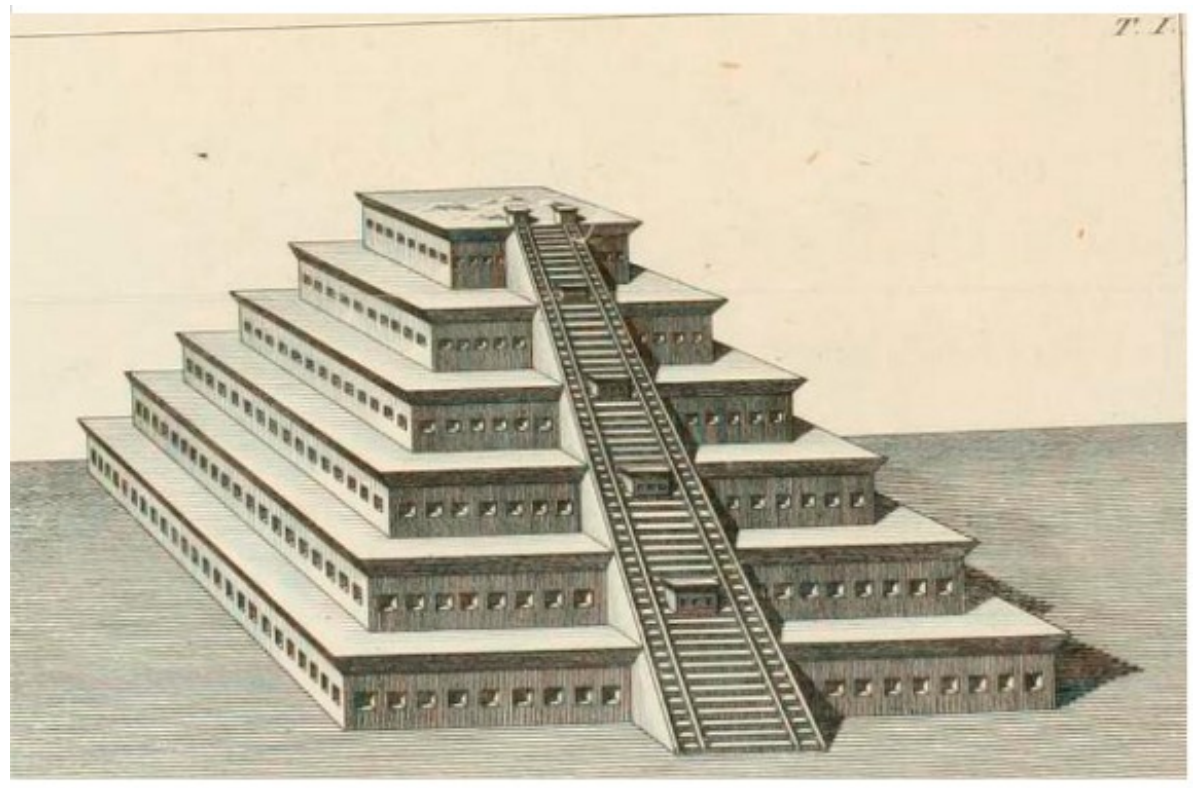

Figura 9.

Due antichi monummenti di architecttura messicana, Pietro Marquez, 1804, p. 48.

En este contexto el ya nutrido fervor nacionalista y el interés ilustrado por el pasado se fortaleció por dos condiciones. La primera, por el interés de Carlos III y su sucesor Carlos IV en la recuperación del pasado occidental y el nacionalismo español, que se materializó en expediciones auspiciadas por la corona para estudiar el pasado de sus colonias; la segunda, consistió en el hallazgo en 1790 de emblemáticos monumentos mexicas.

El segundo conde de Revillagigedo, virrey de la Nueva España, ejecutó numerosas obras urbanas en la Ciudad de México, entre ellas, el despeje de su plaza principal que requirió demoler algunas construcciones y una nivelación del terreno para lo cual se retiró aproximadamente metro y medio de tierra (López, 2015). De tal empresa resultó el hallazgo de decenas de esculturas mexicas, como el calendario azteca o piedra del sol, la piedra de Tizoc y la Coatlicue. A diferencia de siglos anteriores, estos hallazgos no fueron destruidos y sirvieron de elementos decorativos en las esquinas de las calles, hermosearon la arquitectura de las mansiones y otras formaron parte de colecciones privadas y públicas (López, 2015).

La Coatlicue fue resguardada en la Real y Pontificia Universidad, por órdenes expresas del virrey mediante un acuerdo con el regidor Bernardo Bonavia, pues este consideró que era "el lugar más apropiado para custodiar este curioso ejemplo de la antigüedad americana” (Bernal, 1992, p. 77), dando pie al primer museo de antigüedades que sería visitado posteriormente por viajeros como Alexander von Humboldt y el inglés William Bullock, quien difundirían en Occidente la historia prehispánica. Mientras que el calendario azteca fue empotrado en una de las paredes de la catedral para su vista pública. El hallazgo fomentó el estudio de las antigüedades, específicamente del calendario azteca y la Coatlicue, al que se dedicaron Antonio León y Gama y Alzate, autores ya reconocidos en los círculos intelectuales europeos. Sus estudios fueron traducidos al italiano por Pedro José Márquez (Bernal, 1992) y, posteriormente, fueron descritos por Guillermo Dupaix en su informe de la Real Expedición Anticuaria.

\section{EL NACIONALISMO ESPAÑOL ALIMENTA EL NACIONALISMO MEXICANO}

Desde el siglo XVI y hasta el XVIII, en Europa se conjuntaron condiciones que transformaron la concepción de los vestigios materiales como fuentes de conocimiento histórico útiles para construir la historia de las 
naciones: el tránsito del Renacimiento a la Ilustración, el surgimiento del nacionalismo europeo a finales del siglo XVIII y el inicio del turismo moderno mediante el grand tour.

El grand tour surgió para complementar la formación de los jóvenes ingleses y, según Ana María Suárez (2012), con otras motivaciones como "prestigio social [...], necesidad de evasión, curiosidad mundana, capricho personal” (p. 256), este fenómeno se desarrolló mayormente en el siglo XVIII. En este momento, contextualizado por la Ilustración, se consideró que la cultura grecorromana era el origen de la civilización occidental y el inicio del progreso histórico de Europa (Soriano, 2011). De modo que, "el origen de las naciones no se busca en las propias ruinas sino en el mundo clásico del cual los Estados más poderosos [...] sienten ser sus legítimos herederos" (Díaz-Andreu, 2014, p. 14). Así, previo al surgimiento del nacionalismo europeo, el grand tour tiene un componente identitario ligado a los vestigios del pasado, puesto que el objetivo era "rescatar, afianzar y afirmar la memoria de Europa" (Soriano, 2011, p. 33).

El grand tour impactó en la práctica cultural de asociar los monumentos del pasado con la identidad de las sociedades en la creación de una red de atractivos relacionados con el pasado y la necesidad de especialistas que lo rescataran. En este contexto, la corona española patrocinó las exploraciones arqueológicas de Herculano a Roque Joaquín Alcubierre, de 1738 a 1780, que sentaron las bases metodológicas de los estudios arqueológicos españoles. Al final del siglo XVIII este viaje era realizado por europeos y norteamericanos y se extendió a las clases medias. Los itinerarios integraron nuevas rutas, como América, para los más aventureros. Entre ellos Guillermo Dupaix que, según Leonardo López (2015), visitó la Nueva España antes de ser comisionado para realizar la Real Expedición Anticuaria.

Con el movimiento de Ilustración se generaron discusiones en distintos ámbitos, pero son de interés las que respondieron a la pérdida paulatina del poder que España había tenido sobre Europa, por su proceso pionero de colonización. Se trató de una lucha de poderes que, en las últimas décadas del siglo XVIII y la primera del siglo XIX, engendró la construcción del nacionalismo español, fortalecido por el interés de la corona española por el pasado. El motor que dinamizó el nacionalismo español fue debatir la "leyenda negra" de España que, de acuerdo con Nicolás Bas (2001), reflejaba la auto-reflexión de los europeos sobre el indio americano, el Nuevo Mundo y las consecuencias del proceso de dominación y la colonización española. Bajo estas ideas se desarrollaron dos vertientes críticas, una de carácter político en contra del gobierno español absolutista y la otra de corte científico.

Las primeras reacciones nacionalistas fueron suscitadas por la vertiente política y surgieron en 1717 por las Cartas persianas de Montesquieu (Bas, 2001), cuyo trasfondo era la crítica al absolutismo y la necesaria disminución del poder mediante su división. El documento ilustra los argumentos de esta leyenda negra, similares a los planteados por Clavijero:

Desde que los españoles, habiendo asolado a la América, exterminaron a sus antiguos moradores, [...] no han podido repoblarla y muy al contrario, [...] se destruyen los destructores a sí propios. [...] Y habiendo conquistado [...] con increíble celeridad inmensos reynos (sic), [...] se ven obligados a destruirlos [...]. Me atrevo a decir que en vez de que pasaran los Españoles a las Indias, convendría hacer que pasaran los indios y los Mestizos a España, convendría restituir a esta monarquía todos sus pueblos dispersos y [...] sería la más formidable potencia de Europa (Montesquieu, 1818, pp. 235-237).

En la vertiente científica, la principal corriente de crítica contra España fue el evolucionismo. Al igual que los ilustrados novohispanos, el diálogo entre occidentales y españoles fue guiado por el debate con De Pauw, Buffon, Raynal y Robertson, para evidenciar la calidad moral de los indios de sus colonias y la valía del proceso civilizatorio de los territorios americanos. La respuesta española surgió a mediados del siglo XVIII cobijada por la crítica histórica, coincidente con la entrada de los borbones a la corona española y su interés por el pasado. De acuerdo con Alicia León y Raquel Gil (2017), a partir de esta corriente, "los restos arqueológicos se empezaron a considerar como fuente de información no contaminada para la Historia” (p. 318). Con el nacionalismo se estableció la relación entre la cultura material y la investigación del pasado, a finales del siglo XVIII y principios del XIX, aunque esta no era la intención de los estudiosos, relación que ya había sido establecida por los criollos en la Nueva España. 
La corona promovió la recolección de objetos y estudios de la época prerromana, medieval y del mundo clásico, reflejada en el apoyo a las excavaciones de Herculano. Sus resultados fueron publicados en la Nueva España y causaron revuelo entre los ilustrados novohispanos, como Alzate y León y Gama, quienes solicitaron a la corona que, al igual que en Italia, se realizaran excavaciones para descubrir e indagar en el pasado mexicano (López, 2015). Sin embargo, con el fervor nacionalista español se sumó el interés por los objetos y edificios antiguos americanos (León y Gil, 2017). La institución promotora de tal ejercicio fue el Real Gabinete de Historia Natural, fundado en 1771 por Carlos III, el cual estableció parámetros para orientar a los funcionarios dedicados al estudio y la recolección de antigüedades con una serie de instrucciones que, según León y Gil (2017), "exigían la validación de datos y la vigilancia del cumplimiento de las mismas" (p. 323).

La primera instrucción fue la de Pedro Franco Dávila, en 1776, en la que ordenaba la recolección de las antigüedades a las que consideraba "curiosidades de arte, como son vestidos, armas, instrumentos, muebles, máquinas, ídolos y otras cosas que usaron los antiguos indios” (Dávila citado en León y Gil, 2017, p. 323). Su instrucción evidenciaba que su valor estaba en sus cualidades físicas o en todo caso estéticas.

Las instrucciones de Antonio de Ulloa, en 1777, representan el viraje hacia la historia crítica porque estableció que las antigüedades son fuente de conocimiento para conocer "lo que fueron los países en los tiempos más remotos [...] con este motivo se procura investigar lo conducente a su averiguación dando noticia de los vestigios que permanezcan" (De Ulloa citado en León y Gil, 2017, p. 328). De Ulloa conocía las antigüedades americanas y planteó clasificarlas como restos muebles e inmuebles. Los primeros los dividió en recipientes de barro u otra materia prima, herramientas de cultivo de piedra, cobre o hueso, armas conocidas en Occidente o que hubiesen conservado su nombre en su lengua original, ídolos y adornos. Los inmuebles eran paredes, zanjas o fosos, entierros, adoratorios, templos y viviendas junto con su distribución interna (León y Gil, 2017).

Con base en la anterior instrucción, Antonio Calderón, por encargo de José de Estachería, realizó exploraciones en Palenque, lugar que pertenecía al territorio de Guatemala. Una vez entregado el informe, en 1785, Estachería redactó una instrucción que representa la conjunción de la historia ilustrada con el nacionalismo. En esta ordena a Calderón que redactara una historia de América para enaltecer a la nación española que estaba siendo atacada por las publicaciones de los evolucionistas. Estachería redacta una nueva instrucción dirigida a Antonio Bernasconi en la que expone los objetivos de la investigación que llevaría a cabo: conocer "la antigüedad, el origen, las actividades comerciales, la importancia de la ciudad, su orden arquitectónico y [...] la causa de su abandono" (Estachería citado en León y Gil, 2017, p. 330), objetivos que expresan lo que la naciente arqueología debía cumplir; de igual manera, en dicha instrucción, también especifica los tipos de materiales a recolectar. El informe de Bernasconi no cumplió con la instrucción, pero incluyó una serie de dibujos de los principales elementos arquitectónicos del sitio y de algunos glifos (De Pedro, 2009), los cuales reflejan el desarrollo del dibujo arqueológico como una herramienta de registro que continuó practicándose con los comisionados posteriores, Antonio del Río y el dibujante Armendáriz. Véase la Figura 10. 


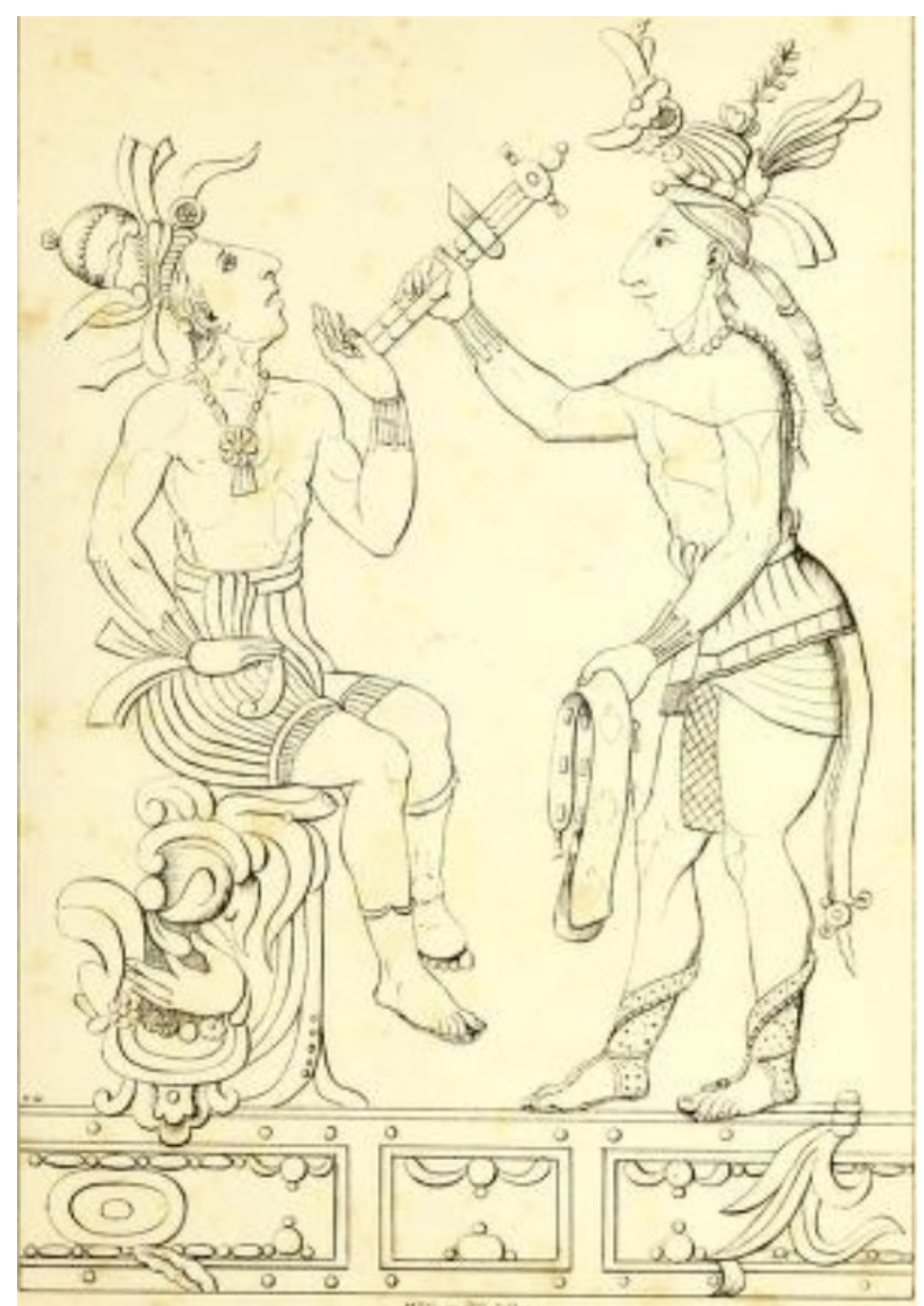

Figura 10.

Description of the Ruins of an Ancient City discovered near in the Kingdom of Guatemala in Spanish America, Antonio del Río, 1822, p. 134.

Otro de los resultados de esta instrucción fue la Expedición Científica Novohispana, cuyos comisionados estuvieron a cargo de Malaspina, quien no desconocía la instrucción de De Ulloa, entre los comisionados estuvo el guatemalteco Antonio Pineda. Sus informes apenas se conocen pero el autor, originalmente encargado de los estudios naturalistas, tenía interés por los monumentos del pasado y, junto con el revuelo que causaron los hallazgos arqueológicos de 1790, también se interesó por los mexicanos (González, 1991). En sus informes registró ruinas de Texcoco, Iztapalapa y Teotihuacán. Sus observaciones de Teotihuacan, plasmadas en el "Diario de México para Guanajuato con rodeo por Zempoala Pachuca, \&c R[ea]l del Monte, hacienda $\mathrm{d}[\mathrm{e}]$ regla, \&c", se enfocan en su extensión y medidas, aquí reporta que tenía una superficie de más de $20 \mathrm{~km}^{2}$ y estuvo habitada por cerca de veinte mil personas. Asimismo señaló las medidas de las pirámides y su estructura de tres o cuatro cuerpos superpuestos, además de percatarse de un monolito (López y Sugiyama, 2015). A Pineda estas obras le parecen meritorias por su técnica y expresa "su admiración ante la grandeza de los monumentos prehispánicos [...]. Reconoce in situ que el espectáculo que tenía a la vista era apabullante y que las pirámides de Teotihuacan eran tal vez émulas de las de Egipto” (González, 1991, p.120). Lamentablemente, Malaspina, organizador de esta expedición, fue acusado de traición y encarcelado a su regreso a España, por lo que los informes científicos no fueron publicados (López y Sugiyama, 2015). 
Según Antonio De Pedro (2009), la instrucción de Ulloa fue difundida entre los virreyes y gobernadores americanos y todo funcionario que investigara las antigüedades debía cumplirla, incluso el reporte de Alzate sobre Xochicalco se ajustaba a ella, convirtiéndose en el primer reglamento de la investigación arqueológica en el actual territorio mexicano. La expedición de mayor envergadura fue la Real Expedición Anticuaria, encargada por Carlos IV a Guillermo Dupaix, quien comisionó a Luciano Castañeda como dibujante. De acuerdo con López (2015), Dupaix, en 1782, en su grand tour recorrió Italia y Grecia y visitó varios gabinetes de curiosidades que impactaron en sus intereses, prueba de ello es que en 1790 viajó a la Ciudad de México y con sus medios recorrió sus alrededores. En este viaje registró monumentos, realizó excavaciones y observó antigüedades en gabinetes de curiosidades privados que dan cuenta de que esta práctica también era común en América entre funcionarios, religiosos, criollos y europeos letrados, y recolectó algunas para su gabinete personal. Dupaix registró sus recorridos en una serie de documentos y dibujos, analizados por López (2015). Su fama llegó a Carlos IV y mediante una real orden de 1804 lo designó "para que se saquen diseños exactos de los edificios y demás monumentos antiguos que conduzcan a la inteligencia de la Historia el País. No menos que a dar idea del gusto y perfección que sus naturales consiguieron en las artes” (López, 2015, p. 44).

La expedición consistió en tres viajes realizados de 1805 a 1808, con el objetivo de investigar todos los monumentos del tiempo anterior a la conquista que puedan existir (Dupaix, 1831) y concluyó por la invasión napoleónica a España y el principio del movimiento de independencia en México. Recorrió distintos sitios con arquitectura monumental como Xochicalco, Mitla, Monte Albán, Zachila y Palenque, los cuales Castañeda registró visualmente en 145 láminas con descripciones de Dupaix, sitios publicados en Descripción de Monumentos Antiguos Mexicanos. Las láminas representan esculturas, bajorrelieves, muchos de ellos con escritura maya, vistas de los edificios y monumentos, planos arquitectónicos y los últimos párrafos y láminas están dedicados a la piedra del sol y a la que denominó como piedra triunfal, hoy conocida como piedra de Tizoc. Dupaix indaga en el desarrollo cultural basado en la arquitectura, la escritura y los objetos que recolectó y los compara con las tradiciones egipcias, persas, chinas e indos (Bernal, 1992). Véase las Figuras 11, 12 y 13.

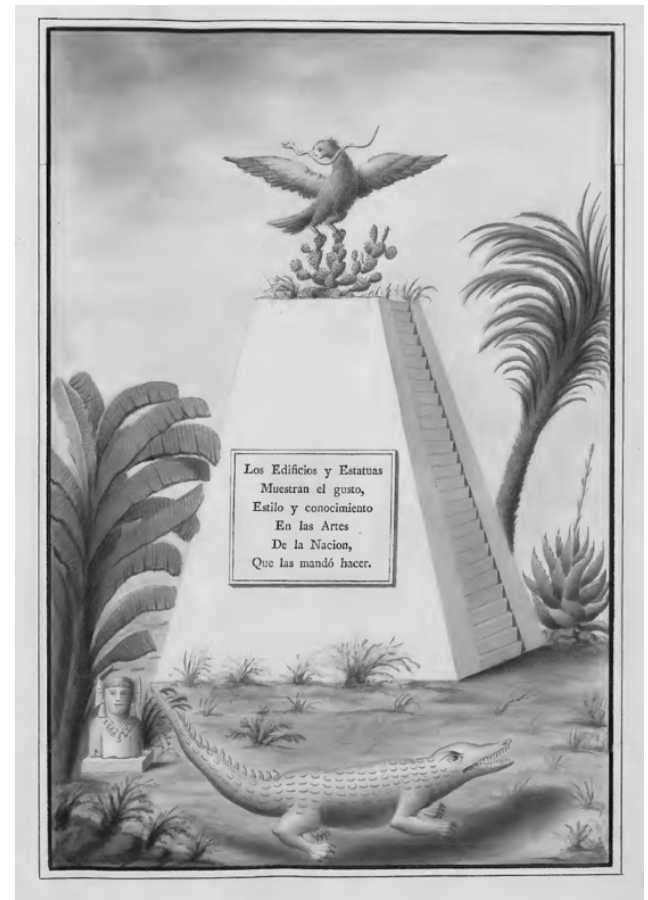

Figura 11.

Portadilla. Colección General de Láminas de los antiguos Monumentos de la Nueva España, Guillermo Dupaix, 1820, p. 4. 


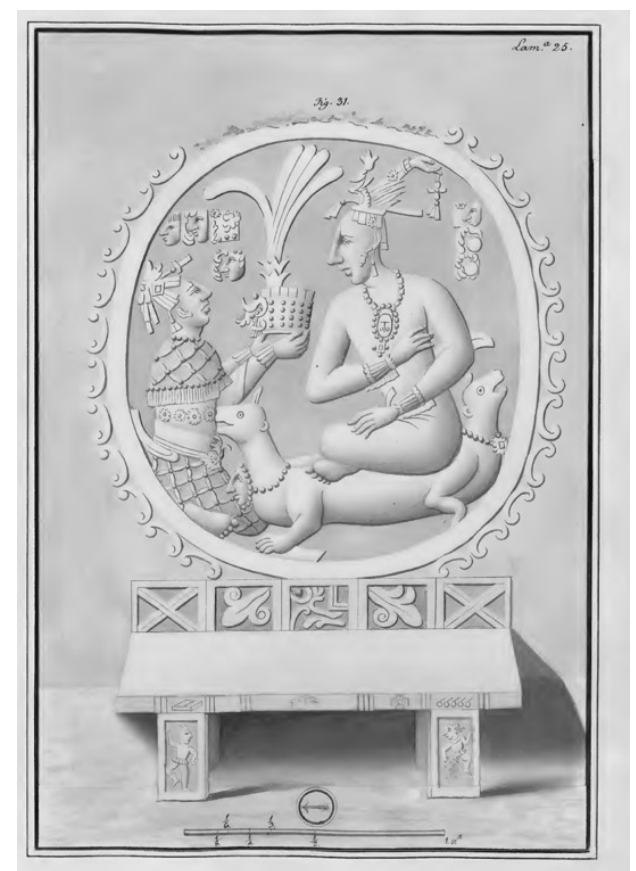

Figura 12.

Colección General de Láminas de los antiguos Monumentos de la Nueva España, Guillermo Dupaix, 1820, p. 108.

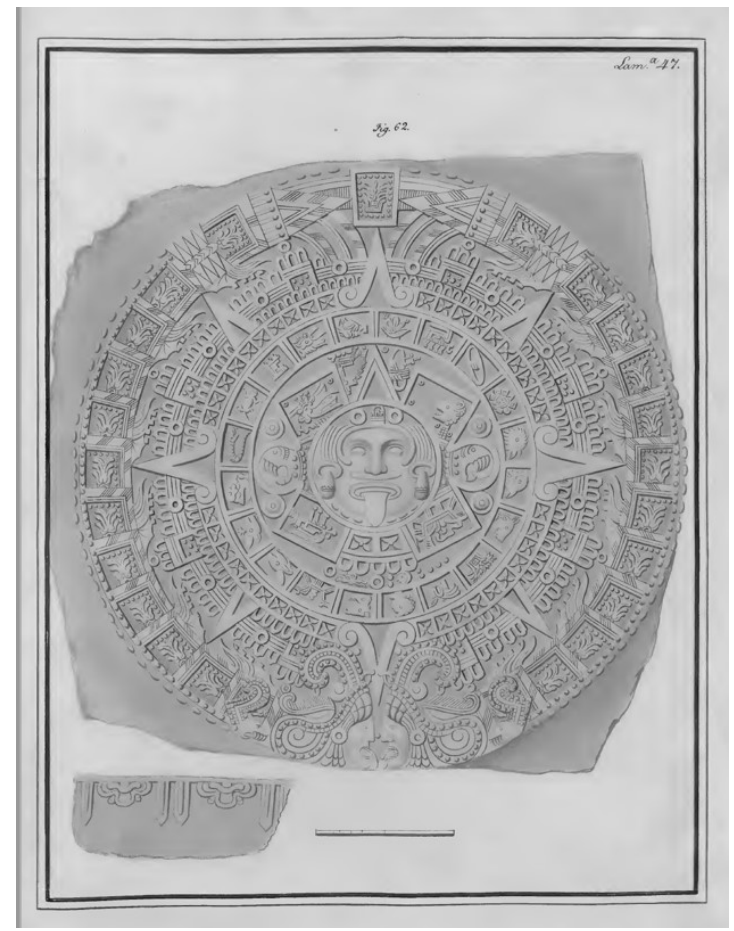

Figura 13.

Colección General de Láminas de los antiguos Monumentos de la Nueva España, Guillermo Dupaix, 1820, p. 130.

El interés central de Dupaix era la descripción detallada, pero de igual forma que los criollos, también dialoga con los autores occidentales evolucionistas. El autor no considera demostrar el origen de los indios porque asumía, de acuerdo con las ideas de la época, que provenían de migraciones de Oriente, pero sí pretendía evidenciar su antigüedad y el desarrollo cultural que habían alcanzado. Así acusa a autores extranjeros, sin referir nombres, quienes por su desconocimiento de: 
las artes antiguas del país de que tratamos, con mucha pretensión, la contemplan como tierra nueva, [...] y así carece de posibilidad que [...] halla podido parir o producir algo del ingenio humano. Este continente es contemporáneo al que llaman antonomásticamente el antiguo [y mi prueba son] los monumentos, cuales por sus construcciones originales y su grande ancianidad son testigos [...] y hacen patente que había en ellos unos imperios de mucha extensión, población y poder [...]. Los viajeros forasteros que han llegado de la Europa, con el intento de recorrer las particularidades dignas de la historia de este gran continente, al juzgarlo, [...] se me figura que hablan de otra tierra [...] pues la desfiguran de tal manera [...], que apenas es conocible (Dupaix 1831, pp. 319-320).

Las descripciones de Xochicalco, Mitla o Palenque son para Dupaix evidencia del desarrollo cultural de los indios, que en algunos casos le parece similar a los antiguos griegos y en otros superior al de los egipcios, tal como interpretaron antes los criollos. Respecto a Mitla, Dupaix (1831) refiere que su arquitectura y sus grecas "bastarían para darle entre todos los órdenes arquitectónicos conocidos, el rango más distinguido" (p. 264) y sobre sus tumbas afirma que: "ningún pueblo del antiguo Continente ha obsequiado con más ternura, a los cuerpos difuntos de sus parientes y amigos, que está nación Zapoteca” (p. 261), incluso ni siquiera los egipcios. Véase la Figura 14.

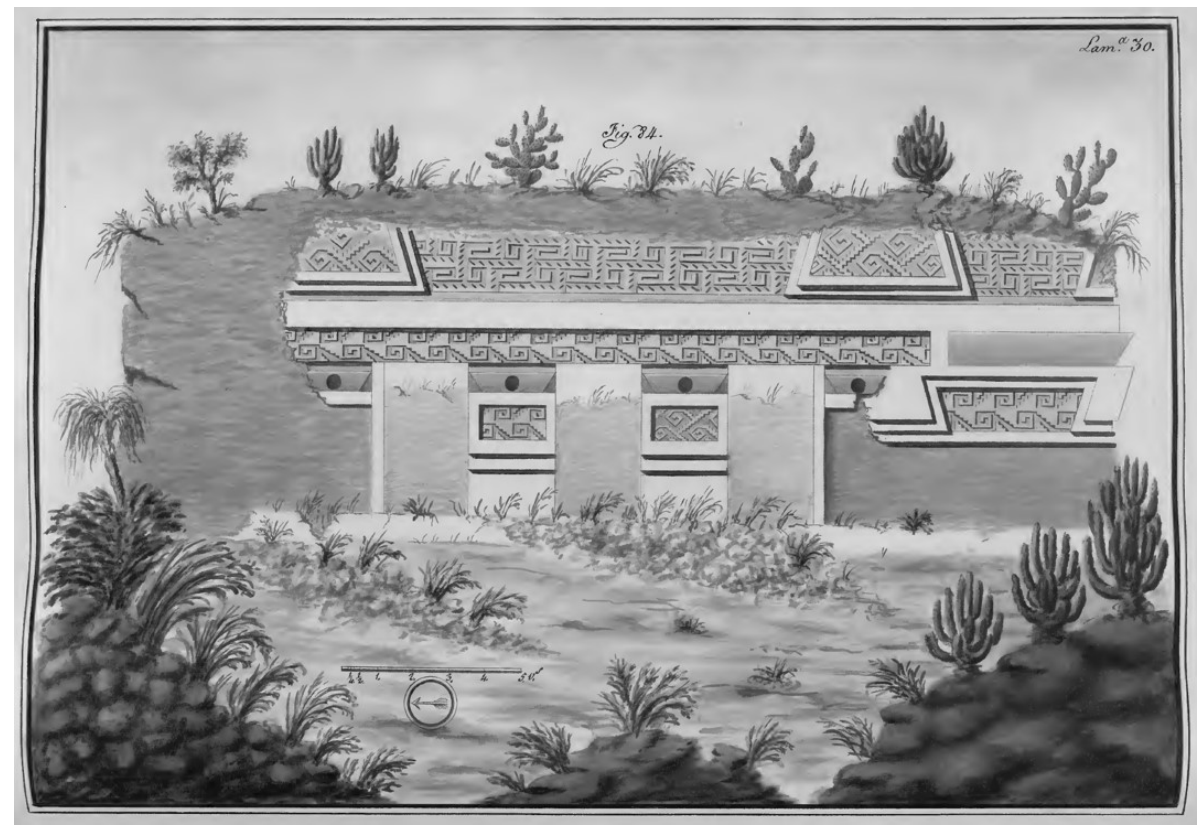

Figura 14.

Segundo palacio de Mitla. Colección General de Láminas de los antiguos Monumentos de la Nueva España, Guillermo Dupaix, 1820, p. 54.

La información de las expediciones auspiciadas por el Real Gabinete de Historia Natural serviría para que Juan Bautista Muñoz, cosmógrafo de Indias, terminara con la comisión encargada por Carlos III de escribir una Nueva Historia del Nuevo Mundo. Muñoz influyó en la instrucción de Estachería sobre la investigación en Palenque, por su interés en mostrar la similitud arquitectónica del uso de la bóveda y el arco de los vestigios romanos con el sitio maya, semejanzas que las investigaciones españolas revelaron (De Pedro, 2009). Muñoz dedicó su obra "al esplendor de la nación, para luz y desengaño general de la república literaria" (Muñoz, 1793, párr. 1) y partió de la duda metódica cartesiana. Cuestiona la historiografía americana, a los humanistas occidentales como Pedro Mártir de Anglería o la obra de Clavijero que calificó de falsas acusaciones contra los españoles. Sin embargo, solo se publicó el primer tomo de la obra que cronológicamente abarcó el descubrimiento de América hasta 1500.

Muñoz tenía la encomienda de aportar a la deconstrucción de la "leyenda negra" de España, pero para los críticos que censuraron la aparición de su segundo tomo no hizo lo suficiente y apoyaba las ideas evolucionistas de De Pauw y Robertson. Al escribir una historia global de América y colocarla en un plano 
universal, en lo general, presentó a los indios con ciertos tintes evolucionistas, sumidos en la ignorancia y la pereza, para poder dialogar con dichos autores, pero su objetivo era argumentar que no todos se encontraban en ese "miserable estado" y la prueba de Muñoz (1793) eran los indios de la Nueva España y Perú: "Las pinturas jeroglíficas de México, los cantares y tradiciones [...], sus establecimientos, artes, religión, política y costumbres, [...] son los documentos más ilustres, las muestras del más alto grado de cultura en el Nuevo Mundo" (p. 15).

Para Muñoz el objetivo de la conquista fue el establecimiento de la fe católica y celebra la empresa de España que, a pesar de la distancia superada por la navegación, las sangrientas batallas, o “la persuasión”, logró dominar un extenso territorio, lo cual le permitió obtener los productos en los que se basó un comercio tan extendido que subió al país a un punto de grandeza:

[...] que difícilmente pueden sostener las fuerzas humanas [...] y fatigada por una larga continuación de esfuerzos extraordinarios, [...] débil por efectos de la prosperidad y abundancia [...] cede varias porciones de aquel terreno inmenso [...]. Y los intereses del Nuevo Mundo vienen finalmente a ser el principal objeto de la Europa (Muñoz, 1793, p. 25).

Con lo anterior Muñoz otorgó a España un papel en la historia europea, a la cual deseaba integrarse, y logra debatir con los evolucionistas y mostrar que existen diversos grados de desarrollo en América sin llegar a compararlos con los alcanzados por la antigüedad occidental. Tal vez lo haría en su tomo no publicado, porque la Real Academia de Historia sugería ilustrarlo con una selección de monumentos para comprobar sus disertaciones (Bas, 2001), o en los inconclusos con la información que aportaría sobre la comparación de los estilos arquitectónicos maya y romano.

Los objetos recogidos por las reales expediciones formaron parte del Real Museo de Ciencias Naturales, en 1867 pasaron al Museo Arqueológico Nacional y en 1941 al Museo de América, donde se encuentran actualmente (Cabello, 2001). Mientras que la publicación de sus informes difundió la historia de un naciente país sobre todo mediante su iconografía y se convirtió en tema de interés y en un imaginario que comenzaba a caracterizar al territorio mexicano.

El informe de Antonio del Río fue publicado en inglés, en 1822, por Henry Berthoud, acompañado de una disertación de Paul Félix Cabrera sobre el origen de los americanos a quien compara con los egipcios. Mientras que el de Dupaix fue publicado en inglés, en 1831, por Lord Kinsborough y en francés por Baradère en 1834. Los gráficos de Bernasconi fueron publicados en Europa y recuperados por Frederick Walldeck en su libro Viaje pintoresco y arqueológico en la provincia de Yucatán durante los años 1834 y 1836, publicado en 1838 y a su vez fueron escogidos para ser incluidos en el libro Monumentos antiguos de México de Charles Étienne Brasseur de Bourbourg, publicado en 1866.

Estas publicaciones alentaron a una oleada de viajeros europeos y norteamericanos, justo antes de la Independencia, como las expediciones de Humboldt, de 1799 y 1804, y otros que emprendieron la segunda colonización del territorio mexicano mediado por intereses comerciales y políticos. Algunos exploraron las ruinas como Desiré Charnay y John Lloyd Stephens y Frederick Catherwood, quienes promovieron aún más ese tipo de exploraciones. Otros daban cuenta de que los vestigios prehispánicos eran una marca definitoria del territorio mexicano. Tal fue el caso del inglés William Bullock, que después de realizar su viaje en 1823, preparó la primera exposición de antigüedades americanas en el Picadilly de Inglaterra, el pionero antropólogo Edward Tylor, Frances Erskine Inglis, conocida como Madamme Calderón de la Barca, y los norteamericanos Brantz Mayer, diplomático, o la escritora Fanny Chambers Gooch, cuyo registro de sus viajes muestran que, además de buscar información estratégica para posibles inversiones, una de sus motivaciones era conocer las antigüedades de su incipiente museo y los templos aún en pie que ya caracterizaban al territorio mexicano. 


\section{Conclusiones}

Los imaginarios de lo que hoy conocemos como patrimonio arqueológico mexicano y que hoy representa a México como una oferta turística, resultaron de un proceso histórico y una dinámica dialógica entre Occidente y América que definió lo que es propio y ajeno, no carente de una dimensión del poder de lo que significó el colonialismo español.

El nacionalismo dinamizó la asociación del pasado prehispánico como un elemento identitario de un territorio y la creación y renovación de sus imaginarios, lo cual permitió posteriormente su mercantilización. Este proceso comenzó en el siglo XVI con la apropiación del conocimiento del territorio desde la mirada occidental para crear una narrativa histórica propia, proceso reflejado, por ejemplo, en la obra de Cervántes. Sin embargo, en ese momento, el pasado de los otros evidenciaba la barbarie que representaba, desde la mirada occidental, su religión y cosmovisión del mundo, lo cual justificaba el proceso civilizatorio español.

La producción científica novohispana de los siglos XVII y XVIII fue la clave para institucionalizar el pasado prehispánico como elemento identitario, pero se fortaleció por el evolucionismo occidental y la afirmación de la "leyenda negra" de España, en donde se comenzó por debatir la justificación del proceso civilizatorio que se vinculó a los cuestionamientos occidentales del colonialismo español.

Las obras de Torquemada, Carlos de Sigüenza y Góngora, De Vetancurt, Boturini o Clavijero muestran la estrategia del debate entre criollos y occidentales sobre la religión de los indios americanos comparándolas con la cristiana o mostrando que, en comparación con otras de las antiguas civilizaciones occidentales, representaba la misma "barbarie". Al mismo tiempo, estas comparaciones evidenciaban el grado de desarrollo alcanzado por los indios para debatir el evolucionismo y sirvieron para enaltecer el pasado y colocarlo a la par de las civilizaciones occidentales, impactando en la transformación de los imaginarios del pasado prehispánico en Occidente y la imaginación del futuro territorio mexicano.

El nacionalismo español se manifestó en la búsqueda de su pasado en los vestigios del imperio romano y permitió establecer las bases metodológicas para su recuperación y registro. Sus avances en la incipiente arqueología impactaron en la exigencia metodológica para su ejercicio en sus colonias. El diálogo no siempre terso entre los criollos novohispanos y los autores occidentales, mismos con los que dialogaron los españoles, confluyó en el interés de construir los límites simbólicos del territorio que ambos imaginaban soberano, en un contexto en que la racionalidad de la Ilustración y el nacionalismo se vincularon.

Mientras para los novohispanos el conocimiento del pasado y su exaltación construyó las raíces de la nación mexicana, para España su nacionalismo pretendía refrendar el poder que alcanzó con su proceso de colonización. Pero mostrar que en sus colonias existieron culturas desarrolladas que formaban parte de su territorio se convirtió en un arma de doble filo, porque "más que ayudar a la consolidación del poder español en las colonias americanas lo perjudicó, desde el momento en que fue utilizado como un arma nacionalista e identitaria de los insurrectos que promovieron la independencia” (León y Gil, 2017, p. 330).

\section{REFERENCIAS}

Alburquerque, L. (2006). Los 'libros de viaje' como género literario. En M. Lucena y J. Pimentel (Eds.), Diez estudios sobre literatura de viajes (pp. 67-87). Madrid: CSIS.

Alzate, J. A. (1792). Descripción de la antigüedades de Xochicalco. En Gaceta de literatura mexicana. Tomo II (pp. 1-16). Recuperado de http://cdigital.dgb.uanl.mx/la/1080024484_C/1080024485_T2/1080024485_66.pdf

Alzate, J. A. (1791). Suplemento a la Gazeta de Literatura. Descripción de las antigüedades de Xochicalco. México: De Zúñiga y Ontiveros. Recuperado de https://archive.org/details/descripciondelas00alza/page/n9/mode/2up

Anderson, B. (2007). Comunidades imaginadas. Reflexiones sobre el origen y la difusión del nacionalismo. México: Fondo de Cultura Económica. 
Bas, N. (2001). Juan Bautista Muñoz y las polémicas con Europa. Estudis: revista de historia moderna, (27), 247-298. Recuperado de http://hdl.handle.net/10550/34337

Benítez, L. (1995). Carlos de Sigüenza y Góngora. Criollo, nacionalista y hombre de ciencia. Anuario Saber Novohispano, 425-435. Recuperado de http://www.iifilologicas.unam.mx/pnovohispano/uploads/95sabernov o/art29_95.pdf

Bernal, I. (1992). Historia de la arqueología en México. México: Porrúa.

Cabello, M. (2001). La formación de las colecciones americanas en España: Evolución de los criterios. Anales del Museo de América, (9), 303-318.

Clavijero, F. J. (1945a). Historia antigua de México. Tomo I. Ciudad de México, México: Porrúa.

Clavijero, F. J. (1945b). Historia antigua de México. Tomo II. Ciudad de México, México: Porrúa.

Clavijero, F. J. (1945c). Historia antigua de México. Tomo III. Ciudad de México, México: Porrúa.

Clavijero, F. J. (1945d). Historia antigua de México. Tomo IV. Ciudad de México, México: Porrúa.

Cervántes, F. (1875). México en 1554. Diálogos. México: Antigua Librería de Andrade y Morales. Recuperado de htt p://cdigital.dgb.uanl.mx/la/1080013288/1080013288.PDF

De Boturini, L. (1746). Idea de una nueva historia general de la América septentrional. Madrid: Ed. Juan Zuñiga. Recuperado de http://www.archive.org/details/ideadeuna

De Pedro, A. (2009). La Real Expedición Anticuaria de México (1805-1808) y la representación del imaginario indianista del siglo XIX. Anales del Museo de América, (17), 42-63. Recuperado de https://dialnet.unirioja.es/ servlet/articulo?codigo $=3659772$

De Sigüenza, C. (1680). Theatro de virtudes politicas que constituyen a un principe advertidas en los monarcas antiguos del mexicano imperio. México: Viuda de Calderón. Recuperado de http://www.cervantesvirtual.com/obra-visor/teatro-de-virtudes-politicas-que-constituyen-a-un-principeadvertidas-en-los-monarcas-antiguos-del-0/html/b9749496-625a-41c6-a948-0f747ca27c03.html

De Sigüenza, C. (1683). Parayso occidental, plantado, y cultivado por la liberal benéfica mano de los muy católicos y poderosos Reyes de España Nuestros Señores en su magnifico Real Convento de Jesús María de México. México: Juan de Ribero. Recuperado de http://www.cervantesvirtual.com/obra-visor/parayso-sic-occidental-plantado-y-cultivado-por-la-liberalbenefica-mano-de-los-muy-catholicos-y-p-0/htmldf6aee15-5433-49d2-b803-11325ae65235_18.html

De Torquemada, J. (s.f.). Monarquía indiana. México: Instituto de Investigaciones Históricas, Universidad Nacional Autónoma de México. Recuperado de http://www.historicas.unam.mx/publicaciones/publicadigital/ monarquia/index.html

De Vetancurt, A. (1870). Teatro mexicano. Descripción breve de los sucesos ejemplares históricos, politicos, militares y religiosos del Nuevo Mundo occidental de las Indias. México: Imprenta de Escalante. Recuperado de http:// cdigital.dgb.uanl.mx/la/1080017653_C/1080017653_T1/1080017653_MA.PDF

Del Río, A. (1822). Description of the Ruins of an Ancient City discovered near in the Kingdom of Guatemala in Spanish America. London: Henry Berthoud. Recuperado de https://archive.org/details/descriptionofrui00roan_0/ page/n5/mode/2up

Díaz-Andreu, M. (2014). Turismo y arqueología. Una mirada histórica a una relación silenciada. Anales de Antropología, 48(2), 9-40.

Dupaix, G. (1831). Viages de Guillermo Dupaix sobre las antigüedades mejicanas. En Lord Kinsbourough (Ed.), Antiquities of Mexico. Vol V (pp. 207-343). Londres: Robert Havell. Recuperado de https://archive.org/details/ AntiquitiesMexi5King/page/ii

Dupaix, G. y Castañeda L. (1820). Colección General de Láminas de los antiguos Monumentos de la Nueva España: que comprende los tres viajes hechos de Real Orden por Don Guillermo Dupaix. México: INAH-Ediciones del Museo Nacional de Antropología. Recuperado de https://archive.org/stream/HArte/HArte\#page/n127/mode/2up

Florescano, E. (1997). Etnia, estado y nación: ensayo sobre las identidades colectivas. México: Aguilar. 
Dra. Eréndira Muñoz Aréyzaga. La construcción del Pasado Prehispánico como elemento identitario de...

Giménez, G. (2000). Identidades étnicas: estado de la cuestión. En L. Reina (Coord.), Los retos de la etnicidad en los estados nación del siglo XXI (pp. 45-70). México: CIESAS, Miguel Ángel Porrúa.

Giménez, G. (2005). Teoría y análisis de la cultura. Vol. 1. México: CONACULTA, ICOCULT.

González, V. (1991). Antonio Pineda. Naturalista y prearqueólogo. En A. Chávez y M. Grijalva (coords.), Cincuenta años de historia en México (pp. 105-121). México: El Colegio de México.

Gutiérrez, N. (2001). Mitos nacionalistas e identidades étnicas: los intelectuales indígenas y el Estado mexicano. México: Plaza y Valdés- CONACULTA.

Hernández, R. (1992). Rasgos de identidad nacional en la conciencia novohispana. Fuentes humanisticas, 2(4), 28-41. Recuperado de http://fuenteshumanisticas.azc.uam.mx/index.php/rfh/article/view/766/752

Hiernaux-Nicolás, D. (2002). Turismo e imaginarios. En L. Villegas (Ed.), Imaginarios sociales y turismo sostenible (pp. 7-36). Costa Rica: Facultad Latinoamericana de Ciencias sociales (FLACSO). Recuperado de http:// biblioteca.clacso.edu.ar/ar/libros/costar/cua123.pdf

Lameiras, J. (1979). Ciencias sociales en México: desarrollo y perspectiva. México: El Colegio de México.

León, A. y Gil, R. (2017). Aproximación al estudio de las antigüedades en la América española en el siglo XVIII a través de tres instrucciones. Revista de Historiografía, (26), 317-334. Recuperado de https://e-revistas.uc3m.es/ index.php/REVHISTO/article/view/3711/2317

López, A. (1973). Hombre-Dios. Religión y politica en el mundo nábuatl. México: UNAM.

López, L. (2015). El capitán Guillermo Dupaix y su álbum arqueológico de 1794. México: Ediciones del Museo Nacional de Antropología, INAH.

López, L. y Sugiyama, S. (2015). Los expedicionarios de Malaspina llegan a Teotihuacan (1791). Arqueología Mexicana, 23(131), 22-33. Recuperado de http://www.mesoweb.com/es/articulos/sub/AM131.pdf

López, L. (2010). Los primeros pasos de un largo trayecto: la ilustración del tema arqueológico en la Nueva España del siglo XVIII. Memorias de la Academia Mexicana de la Historia, 51, 203-263. Recuperado de http:// www.mesoweb.com/es/articulos/sub/Discurso-AMH.pdf

Malaspina, A. y De Bustamante, J. (1885). Viaje politico-cientifico alrededor del mundo por las corbetas Descubierta y Atrevida al mando de Alejandro Malaspina y Don José de Bustamante desde 1789 a 1794. (2 Ed.). Madrid: Imprenta de la viuda e hijos de Abienzo. Recuperado de https://www.biodiversitylibrary.org/ item/85937\#page/101/mode/lup

Marquez, P. (1804). Due Antichi Monummenti di Architettura Messicana. Roma: Presso il Salomoni. Recuperado de https://archive.org/details/dueantichimonume00marq/page/n3/mode/2up

Martínez, M. (2016). La construcción del Museo Nacional de Arqueología e Historia (1867-1910). De la colección privada a la pública. (Tesis de maestría). Instituto Mora, Ciudad de México.

Montesquieu, Ch. (1818). Cartas persianas. París: Nimes, Imprenta de P. Dueand-Belle. Recuperado de http:// fama2.us.es/fde/cartasPersianas.pdf

Muñoz, J. B. (1793). Historia del Nuevo Mundo. Tomo I, Madrid: Viuda de Ibarra. Recuperado de https:// play.google.com/books/reader?id=J-M8AAAAYAAJ\&hl=es_419\&pg=GBS.PP5

Pérez, R. (2006). Down Mexico Way. Estereotipos y turismo norteamericano en el México de 1922. Cuadernos de Patrimonio Culturaly Turismo, (14), 14-32.

Rubial, A. (2002). Nueva España: imágenes de una identidad unificada. En E. Florescano (Comp.), Espejo Mexicano (pp. 72-115). México: Conaculta, FCE.

Schávelzon, D. (1983). La primera excavación arqueológica de América. Teotihuacán en 1676. Anales de Antropología, 20(1), 121-135. Recuperado de http://revistas.unam.mx/index.php/antropologia/article/viewFile/413/393

Sebastiani, S. (2011). Las escrituras de la historia del Nuevo Mundo: Clavijero y Robertson en el contexto de la Ilustración europea. Historia y grafía, (37), 203-236.

Soriano, N. (2011). El viaje y lo monstruoso en el siglo XVIII por una ética-estética del Grand Tour. Nómadas. Revista Critica de Ciencias Sociales y Jurídicas, 32(4), 255- 288. Recuperado de https://revistas.ucm.es/index.php/ NOMA/article/view/38080/36834 
Revista Humanidades, 2020, 10(2), Julio-Diciembre, ISSN: 2215-3934,

Suárez, A. M. (2012). El grand tour: un viaje emprendido con la mirada de Ulises. Isumu, 15, 253-279. Recuperado de https://revistas.uam.es/isimu/article/view/3332/3546

CC BY-NC-ND 